\title{
Japanese Elachista mining on the leaf of woody Poaceae (Lepidoptera: Elachistidae s. str.)
}

\author{
Kazuhiro Sugisima \& Lauri Kaila
}

Sugisima, K. \& Kaila, L. 2005: Japanese Elachista mining on the leaf of woody Poaceae (Lepidoptera: Elachistidae s. str.). — Entomol. Fennica 16: 83-102.

Elachista canis Parenti, E. sasae Sinev \& Sruoga, and E. planicara Kaila are redescribed on the basis of Japanese specimens including many bred ones. Larvae of these species are leaf-miners on woody Poaceae. The female of E. canis and the male of E. planicara are described for the first time. In the original description of $E$. sasae, the characterisation of the female has proved to be based on specimens of E. planicara, and thus the female of E. sasae is described for the first time. Based on morphological features, E. canis and E. sasae are considered to be very close to each other and are likely to represent one of the basal lineages of the sister-clade of the E. bifasciella-group, and E. planicara is likely to be an Oriental representative of the E. saccharella-group.

K. Sugisima, Systematic Entomology, Faculty of Agriculture, Hokkaido University, Sapporo,060-8589 Japan; E-mail: ksugi@res.agr.hokudai.ac.jp

L. Kaila, Finnish Museum of Natural History, Division of Entomology, P. O. Box 17, FI-00014University of Helsinki, Finland; E-mail: Ikaila@mappi.helsinki.fi

Received 3 July 2004, accepted 2 October 2004

\section{Introduction}

The genus Elachista Treitschke (Lepidoptera: Elachistidae) is well known for the considerably close association with monocots, especially Juncaceae, Cyperaceae, and Poaceae (TraugottOlsen \& Nielsen 1977, Parenti \& Varalda 1994). However, only two Elachista species have been reported to use woody Poaceae as the larval food. Fletcher (1933) reported that Elachista endobela Meyrick mined on the leaf of Bambusa in India. Sinev and Sruoga (1995) described E. sasae on the basis of specimens reared from leaf-miners on Sasa kurilensis in the Russian Far East. Such a small number of records does not necessarily mean that woody Poaceae would be exceptional food plants of Elachista. These two records are from the Oriental and east Palaearctic regions. In these regions, woody Poaceae are represented by a great species diversity. On the other hand, immature stages of Elachista are poorly known there, as compared to, e.g. in the western Palaearctic region, where woody Poaceae do not naturally grow. Therefore, it is possible that many Elachista species associated with woody Poaceae remain unknown there. For a better understanding about the evolutionary history of the relation between Elachista species and their food plants, any new reports of the Elachista species on woody Poaceae are significant.

Recent investigations into the elachistid fauna in Japan, including breeding of numerous leafmining caterpillars, have revealed that three Elachista species feed on leaves of woody Poaceae. They are Elachista canis Parenti, E. sasae Sinev \& Sruoga and E. planicara Kaila. To 
draw attention to generally little studied but potentially diverse Elachista on woody Poaceae, these species are redescribed on the basis of many Japanese samples, with detailed information on the life-history of each species. A taxonomic correction is given to $E$. sasae. Discussions are given on the phylogenetic position of each species.

Observations of the life history and the redescriptions of species were made by the first author. The discussion was prepared by both authors.

\section{Material and methods}

All specimens examined in this study were collected in Japan. Japan is divided into five major island groups, Hokkaidô, Honsyû, Sikoku, Kyûsyû and Ryûkyû and they are used as headings. For Honsyû, Sikoku, and Kyûsyû prefecture-level subdivisions, the name of which ends with -ken, -hu, or -to, are applied as subheadings. Specimens are listed according to localities within the heading or subheading. For reference of life-historical traits, reared adult specimens are provided not only with the emergence date after "em." but also with the collecting date of the larva after "col." if available from the label. The food plant names are given after "ex". When the rearing number is specified in the label, it is given in the parenthesis after the food plant name. Names of collectors are omitted; most specimens were collected by the first author, and other collectors who offered specimens are mentioned in the acknowledgements of this paper. Most specimens are deposited in SEHU (Systematic Entomology, Hokkaido University, Sapporo, Japan), and in this case the repository is omitted. In other cases, repositories are mentioned in parenthesis at the end of specimen data of each locality, using the following abbreviations: FMNH (Finnish Museum of Natural History, Helsinki, Finland); OPU (Entomological Laboratory, Agricultural School of Osaka Prefecture University, Sakai, Japan); PCNH (personal collection of N. Hirano at Hata, Nagano-ken; this collection will be deposited in OPU).

\section{Taxonomy: redescriptions and corrections}

\subsection{Elachista canis Parenti, 1983 (Figs. 1-9)}

Elachista canis Parenti, 1983: 12-13; Sruoga, 1995: 160.

Specimens examined. Holotype: 今̄, [3440.6 N 135 51.3 E], Nara-kôen, Nara-si, Nara-ken, Honsyû, Japan, [col. 19.VII.1965 (H. Kuroko, pers. comm.)], em. 1.VIII.1965, ex Eccoilopus cotulifer [written in Japanese common name], $\mathrm{H}$. Kuroko leg.; genitalia preparation no. 3802 ऽ, U. Parenti; deposited in OPU.

Other specimens examined. Hokkaidô 1 q, Wakkanai-si, 31.VII.1958; 1 , Minamisimonuma, Horonobe-tyô 22.VII.1993; 1 ổ, Mosiri, Horokanai-tyô 21.VII.1991; 3 §22 q, Miwa, Kosimizu-tyô (1 ふૈ, 22.VII.1989; 2 ふ઼, 2327.VI.1999; 1 ㅇ, 19.VII.1999; 1 ㅇ, 10.VII.2001) (1 $\widehat{\jmath}$ in FMNH); 1 +, Ninisibetu, Akan-tyô 23.VII.1996; 1 ㅇ, Nukabira-tyô 14.VII.1959; 2 đ., Tomurausi-yama, em. 9-11.VI.1983, ex Sasa sp.; 2 §, Nopporo, Ebetu-si, 7.VII.1992; 1 § 2 ㅇ, Sapporo, Sapporo-si (1 ㅈ 1 \%, em. 23.VI.1982, ex Sasa senanensis; 1 ๙ૈ, 25.VII.1983); 3 ๙ 5 ㅇ, Hokkaido Univ., Sapporo-si [1 9 , col. 26.V.1996, em. 11.VI.1996, ex Sasa senanensis (00210); 1 đ 2 o, col. 17.V.2000, em. 1.VI.2000, ex Sasa senanensis (00340); 1 ๆ, 7.VII.2000; 2 ภे 1 \%, col. 3.V.2001, em. 18-20.V.2001, ex Sasa senanensis (00417)] ( 1 ô 1 \% in FMNH); 1 q, Teine, Sapporo-si, 30.VI.1959; 1 ô, Otarunaigawa, Sapporo-si, 29-31.VII.1968; 1 $\curvearrowright$, Muineyama, Sapporo-si, 8.VIII.1972; 1 गे, Sinsennuma, Kyôwa-tyô col. 1.VI.1998, em. 15.VI. 1998, ex Sasa sp. (00297); 1 ๆ, Higasikawa,

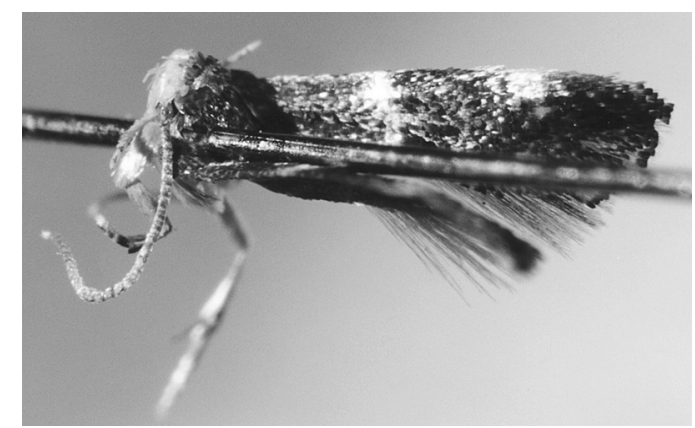

Fig. 1. Elachista canis Parenti, holotype $\overbrace{}^{\jmath}$. 
Fig. 2. Elachista canis Parenti, ô genitalia (holotype, U. Parenti 3802). Scale $0.1 \mathrm{~mm}$.
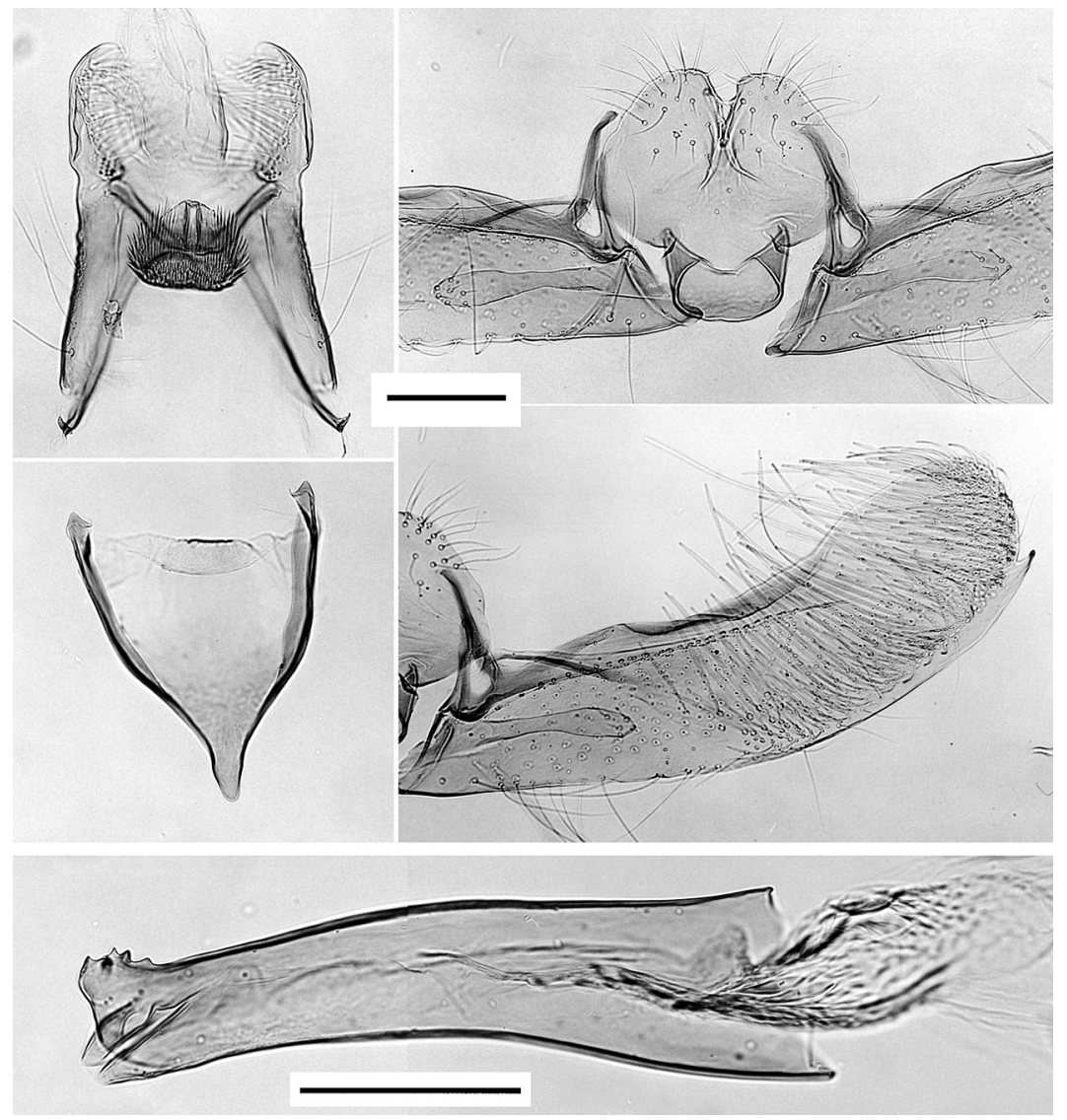

Kuromatunai-tyô 22.VII.1997; 1 ㅇ, Gamusi, Atusabu-tyô 12.VII.1958. Honsyû Iwate-ken: 1 q, Kuriyagawa, 21.VI.1979. Ibaraki-ken: 1 ふૈ, Utihara-tyô em. 26.IV.1983, ex Pleioblastus chino. Saitama-ken: 1 $\hat{\text {, }}$, Hidaka-si, em. 30.IV. 1994, ex Pleioblastus sp. (00002) (in FMNH). Tôkyô-to: 1 đ̃, Yugi, Hatiôzi-si, 30.X.1996; 1 స

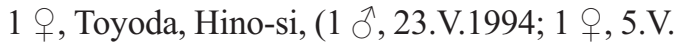
1997); 1 †, Hodokubo, Hino-si, 5.V.1997. Sizuoka-ken: 1 q, Kawadu-tyô 9.V.1995. Mieken: 1 †, Kuwana-si, em. 4.V.1983, ex

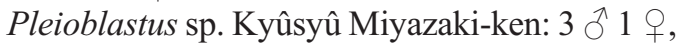
Isigami-zinzya, Takatiho-tyô col. 19.IV.1995, em. 7-9.V.1995, ex Pleioblastus argenteostriatus (00059) (1 đ̂̉ in OPU). Ryûkyû 1 ô, Ie-rind Okinawa-hontô col. 21.III.2002, em. 13.IV.2002, ex Bambusa sp. (00546); 2 ก 6 ㅇ, Yonaha-dake, Okinawa-hontô col. 22.III.2002, em. 12-15.IV. 2002, ex Bambusa sp. (00548) (1 9 in FMNH; 1 $\rightarrow$ in OPU).

Redescription. Male (Figs. 1, 3a) and female
(Fig. 3b). Forewing length $ð 3.1-4.3 \mathrm{~mm}$, ㅇ 3.5$4.4 \mathrm{~mm}$. Face somewhat various in colour, creamwhitish to pale grey-ochreous in most specimens, and lead-greyish in Ryûkyû specimens (creamwhitish in holotype); neck tuft dark greyish, tinged with brown. Labial palpus approximately 1.7 length of width of head, pale ochreous in ground colour, dark greyish outwards and at apex; dark greyish patches present near apex of second segment and at base and middle of third segment, often forming a ring; distal end of the second segment with a complete pale ochreous ring. Thorax and tegula black-greyish. Tibiae and tarsi dark greyish outwards, ochreous inwards and at apex of each segment, with terminal segment often entirely ochreous; a broad pale ochreous ring present near the base of hind tibia. Forewing blackish, sparsely mottled with greyish bases of scales in male, slightly lustrous in female, with three silvery markings larger and more distinct in female: a transverse fascia at $1 / 3$, run- 


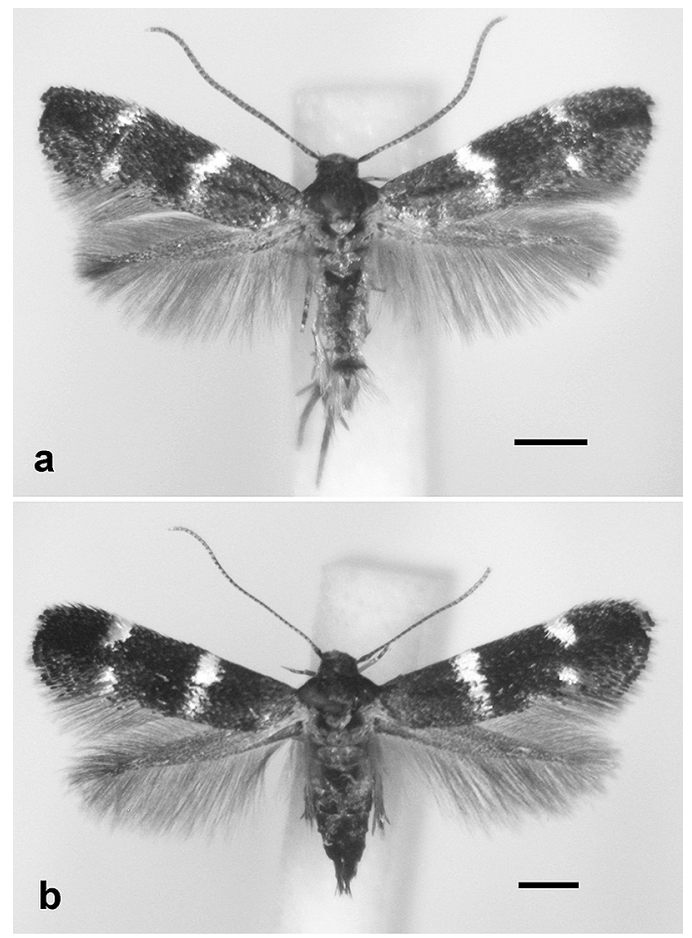

Fig. 3. Elachista canis Parenti, moths reared from leaf-miners on Sasa senanensis at Hokkaido Univ., Sapporo-si. a. ô. b. ㅇ. S. Scale bars $1 \mathrm{~mm}$.

ning from costal margin beyond fold and often reaching hind margin, a triangular costal spot present at $2 / 3$, a triangular tornal spot being opposite to the costal one, most indistinct among the markings and separated from the costal one; a cir-

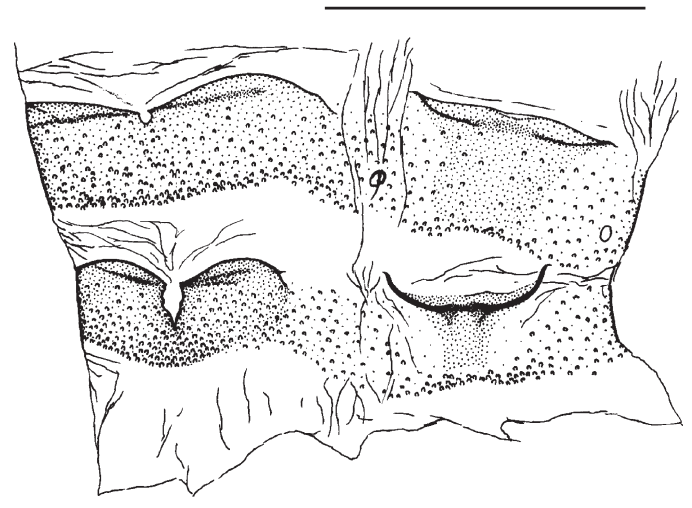

Fig. 4. Elachista canis Parenti, $\partial$ terminal segments of non-genital abdomen, tergite to right, sternite to left (Sinsen-numa, Kyôwa-tyô reared from Sasa sp.), slide no. 0761 of K. Sugisima. Scale $0.5 \mathrm{~mm}$.

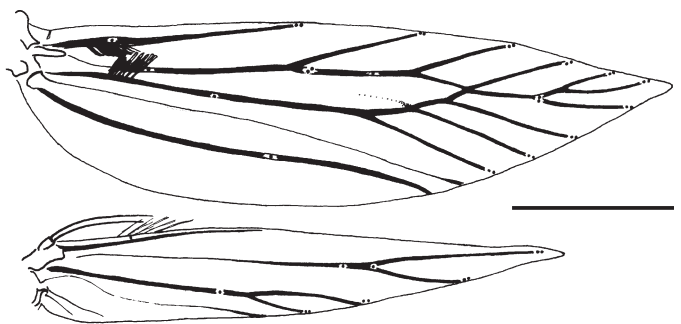

Fig. 5. Elachista canis Parenti, ㅇ, wing venations (Hokkaido Univ., Sapporo-si, reared from Sasa senanensis), slide no. 0808 of K. Sugisima; dots indicating positions of campaniform sensilla. Scale $1 \mathrm{~mm}$.

cular tuft of raised black scales at 3/5 of fold; cilia dark greyish, with blackish cilia line. Hindwing and cilia dark greyish, tinged with brown. Eighth abdominal tergite with a strongly sclerotised bow-shaped ridge nearly along cephalic margin (Fig. 4); a similar but much less-developed ridge present in seventh tergite (Fig. 4); seventh and eighth sternites with cephalic margin medially indented and sometimes incised, much more deeply in eighth (Fig. 4).

Wing venation (Fig. 5). Forewing with R3 arising from end of cell or short-stalked with common stem of R4+5 and M1; M1 long-stalked with R4+5. Hindwing without M2 and M3.

Male genitalia (Figs. 2,6). Uncus lobes bluntly semicircular, outwards overhanging considerably; ventral surface densely covered with long setae, even in area near socius; distance between lobes much wider than base of lobe. Tegumen almost as long as wide, nearly parallelsided, with the cephalic margin strongly sclerotised and concave very deeply towards uncus. Gnathos knob sub-spherical. Valva widening towards apex; costa very strongly sclerotised, with hump around $1 / 3$; ventral margin evenly curving, with its distal end forming a spine. Digitate processes clavate, 1/4 the length of valva, with 4-7 short setae around apex. Juxta lobes separated from each other by a very narrow cleavage, bluntly triangular, with about 15 long setae apically and fewer short ones medio-basally; lateral part of the lobe considerably protruding, smoothly curving in dorso-cephalic direction (but usually folded when mounted on slide in standard position); lateral pockets of juxta well developed. Vinculum tapering towards distinct saccus. Aedeagus nearly as long as valva, equally 
Fig. 6. Elachista canis Parenti, ổ genitalia (Sinsen-numa, Kyôwa-tyô reared from Sasa sp.), slide no. 0761 of K. Sugisima. a. Whole genitalia; scale $0.5 \mathrm{~mm}$. b. Magnified view of juxta and cornuti; "divt" indicating diverticulum; scale $0.1 \mathrm{~mm}$.

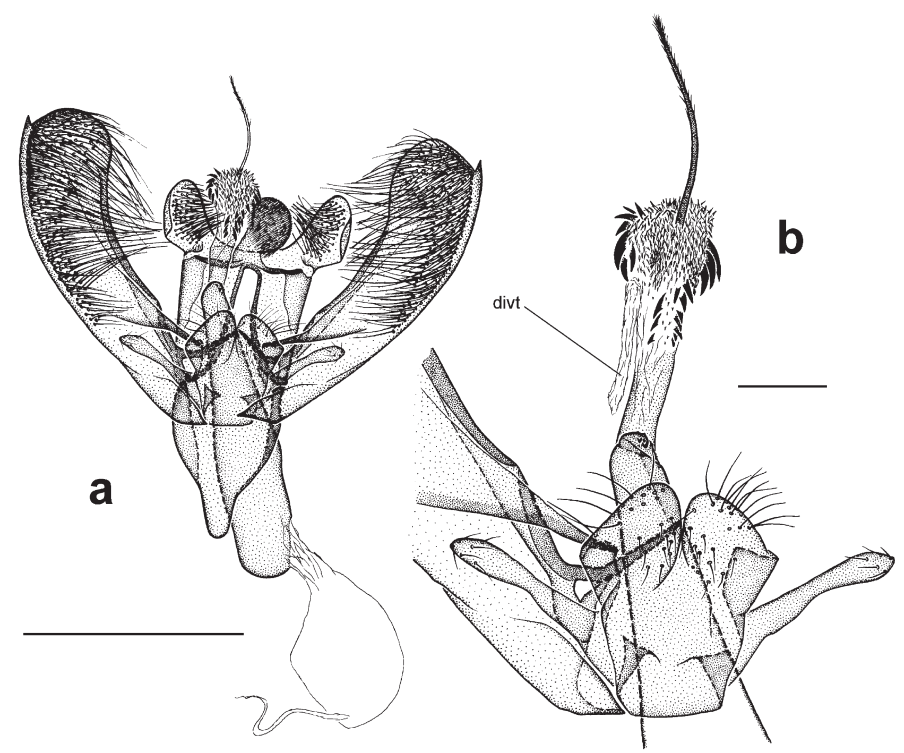

wide in basal half, tapering in distal half, apically (Fig. 2) with a patch of several pointed tubercles on ventral surface. Vesica (Fig. 6b) slightly sclerotised in basal area, with cornuti situated beyond the sclerotised area, and with a diverticulum beyond cornuti; cornuti composed of a group of numerous small teeth, a few series of several much larger stout teeth, and a slender curved rod which is nearly half as long as aedeagus and splintery in its distal 2/3.

Female genitalia (Fig. 7). Papillae anales semi-elliptical in lateral view, ventrally and laterally ornamented with stout setae of various length. Apophyses anteriores 3/5-2/3 as long as apophyses posteriores. Ostium opening between the seventh and eighth sternites, 1/3-2/5 as wide as the eighth sternite. Antrum cup-shaped, ornamented with dense spines except for cephalic end being membranous. Ductus bursae strongly sclerotised in caudal 2/5; this sclerotised part $1 / 3$ as wide as antrum around caudal end and then gradually widening; the remaining $3 / 5$ of ductus bursae membranous, almost equally wide, with fine spines near corpus bursae; around border of sclerotised and membranous parts, several longitudinal folds present and ductus seminalis branching off. Corpus bursae ovate, with minute

Fig. 7. Elachista canis Parenti, $q$ genitalia (Hokkaido Univ., Sapporo-si, reared from Sasa senanensis), slide no. 0762 of K. Sugisima. Scale $0.5 \mathrm{~mm}$.

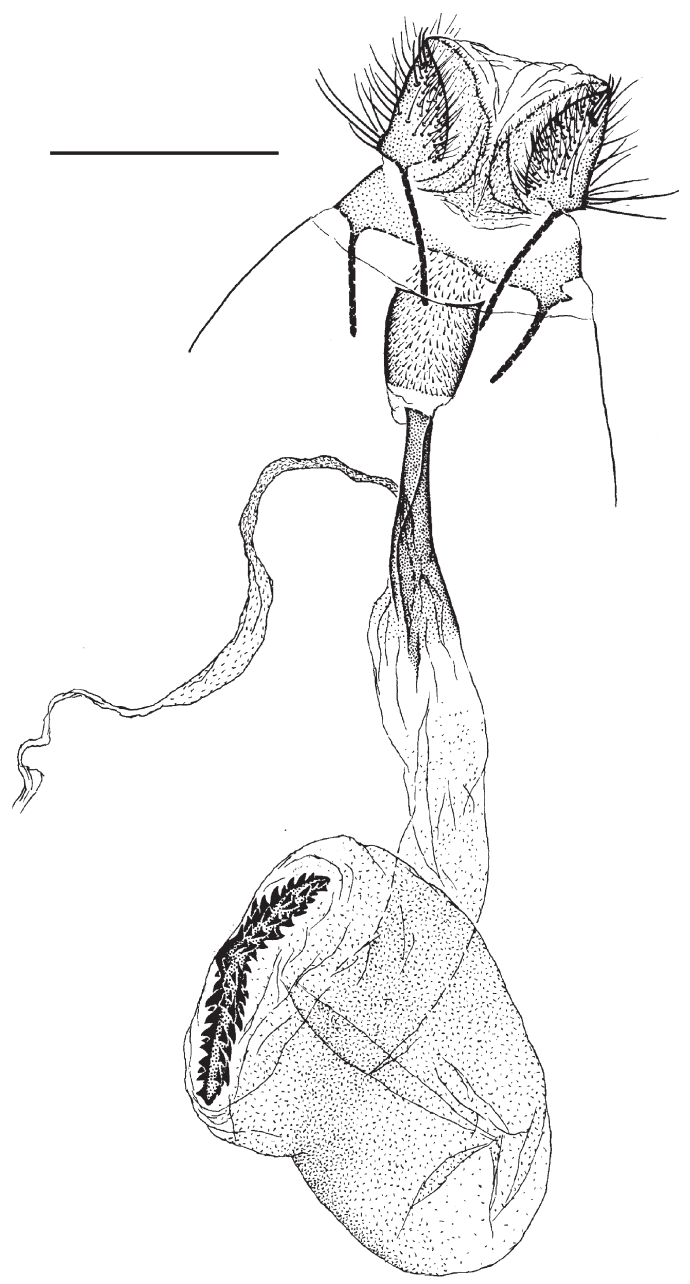



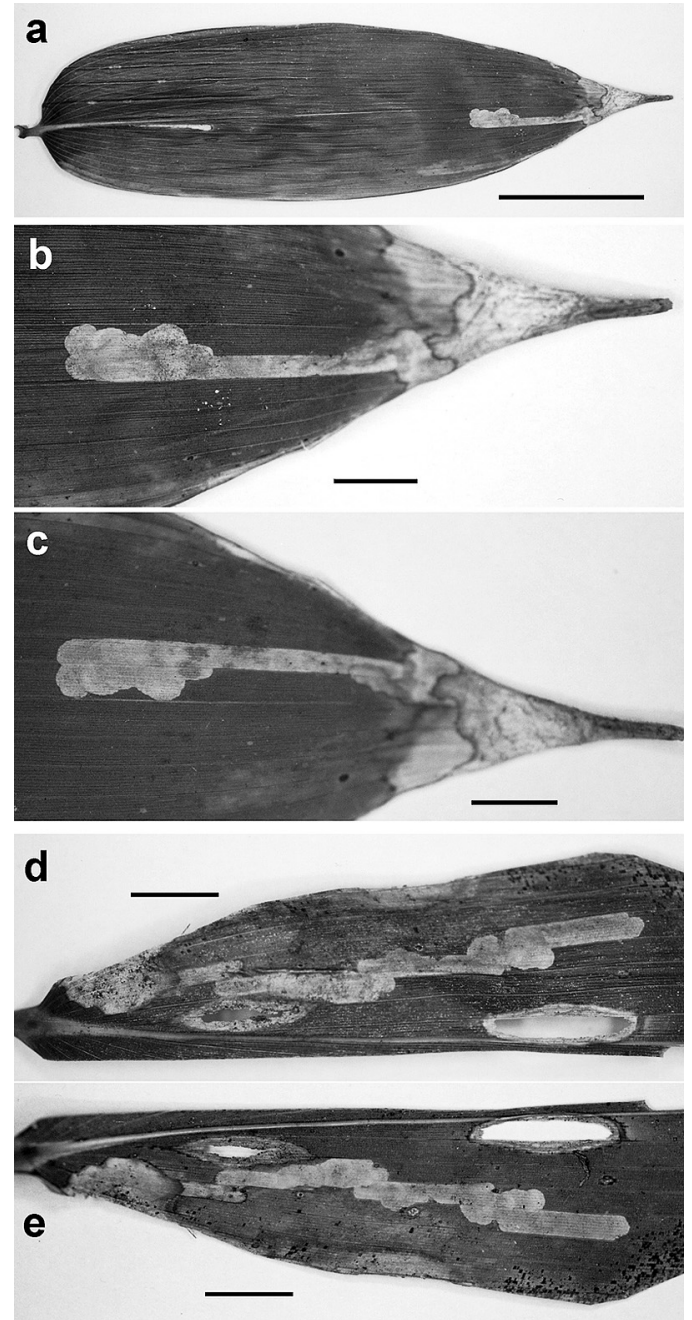

Fig. 8. Elachista canis Parenti, larval mines (Hokkaido Univ., Sapporo-si, on leaf of Sasa senanensis). Scale $5 \mathrm{~cm}$ in (a), $1 \mathrm{~cm}$ in (b-e). a. A mine near leaf tip, whole leaf. b. Magnified view of mine, upper side. c. Magnified view of mine, underside. d. Mine near leaf base, upper side. e. Mine near leaf base, underside.

spines scattered; signum bluntly boomerangshaped, as wide as corpus bursae, with some series of sub-triangular stout teeth.

Distribution. Japan (Hokkaidô, Honsyû, Kyûsyû, Ryûkyû ; the Russian Far East (Sakhalin) (Sruoga 1995).

Food plants. Three genera of woody Poaceae are recognised in this study: Sasa, Pleioblastus, and Bambusa. The holotype was reared from a leaf-miner on Eccoilopus cotulifer (see Remarks).

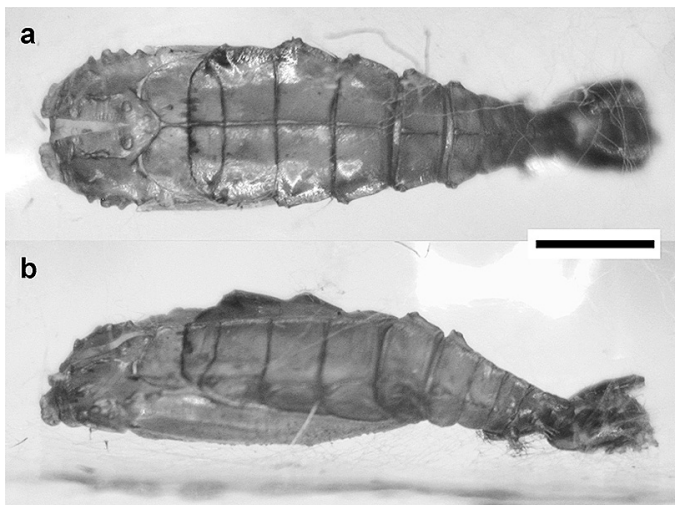

Fig. 9. Elachista canis Parenti, pupa (Hokkaido Univ., Sapporo-si, reared from Sasa senanensis). a. Dorsal view. b. Dorso-lateral view. Scale $1 \mathrm{~mm}$.

Biology. The description below is based on observations at Sapporo-si, where biology was observed repeatedly between autumn and the following summer. The larva is a leaf-miner and reaches its full growth in a single mine. The mine (Fig. 8) tends to be found in the apical part of the leaf(Fig. 8a), but rarely near the base of leaf (Fig. $8 \mathrm{~d}-\mathrm{e})$; little tissue remains uneaten. It starts just below the egg-shell that is adhered to the upper surface of the leaf, usually near the leaf-edge. The earlier mine is sinuate-linear and extends for at most a few centimeters, with little particular tendencies in direction. Then, after hibernation, the mine abruptly broadens extending towards the leaf-base, and finally becomes an elongate blotch. When made near the apex of the leaf, the mine is little prevented from broadening beyond veins, but otherwise it tends to be restricted within the area between strong veins. Excrements are scattered irregularly inside the mine. The larva is whitish, with the head and the prothoracic shields dark brownish. In rearing condition, pupation takes place on both angled and non-angled places, in a ocoon of several very rough transverse series of silk filaments. The pupa (Fig. 9) is supported by a silk girdle and the cremaster, dark brownish, with the dorsal ridge and a pair of more distinct dorso-lateral ridges on the abdomen. The adult is occasionally found resting on the leaf of food plants in early July, and is sometimes caught at light trap.

Judging from collecting dates, one or more non-overwintering generations are likely to occur in southern districts. 
Remarks. Parenti (1983) described this species on the basis of a single male specimen reared from a leaf-miner on Eccoilopus cotulifer, with its face cream-whitish. He emphasised the peculiarity of this species on the basis of the structures of the male genitalia, but as such structures he only specified the two small lobes at the apex of the aedeagus [figure 2 and "Tav 1" in Parenti (1983)]. Comparison to 15 slides of the male genitalia, however, the paired obes in the holotype slide have proved to be simply a preparation artifact. Nevertheless, the peculiarity of this species within Elachista is remarkable with regard to the structures of the aedeagus. No other species in the subgenus Elachista has such a long splintery rod on the vesica, and a group of tubercles on the apex of the aedeagus is shared only by E. sasae (see below).

No significant differences were detected in the genitalia structures of the specimens examined in this study including the holotype. The holotype is labelled as being reared from Eccoilopus cotulifer, and this is the only record from herbaceous Poaceae. The label data of the holotype are fairly reliable because in the field note of H. Kuroko, who collected and reared the holotype, there is a statement, "on" 19.vii.1965 at Nara-kôen, I collected an Elachista leaf-miner on Eccoilopus cotulifer (H. Kuroko, pers. comm.). The holotype probably belongs to the nonoverwintering generation, but no reared specimens of the generation were available in this study. Reared specimens of non-overwintering generation are necessary for concluding whether the holotype and the specimens from woody Poaceae actually belong to the same species.

\subsection{Elachista sasae Sinev \& Sruoga, 1995 (Figs. 10-15)}

Elachista sasae Sinev \& Sruoga, 1995: 130-132. Specimens examined. Hokkaidô: 2 , Horonobe, Horonobe-tyô, em. 3-5.VII.1996, ex Sasa sp. (00225); 10 đ 5 ㅇ, Miwa, Kosimizu-tyô [1 Љ 1 , 22.VI-25.VII.1997; 2 ○ 2 ㅇ, 23.VI19.VII.1999; 4 ठ 1 ㅇ, 17-30.VIII.1999; 3 ふぇ 1 ㅇ, col. 18.VIII.2002, em. 29.VIII-5.IX.2002, ex Sasa senanensis (00617)] (2 $\bigcirc$ in FMNH); 1 , Kamitoku, Kosimizu-tyô, 14.VII.1996; 1 ㅇ,

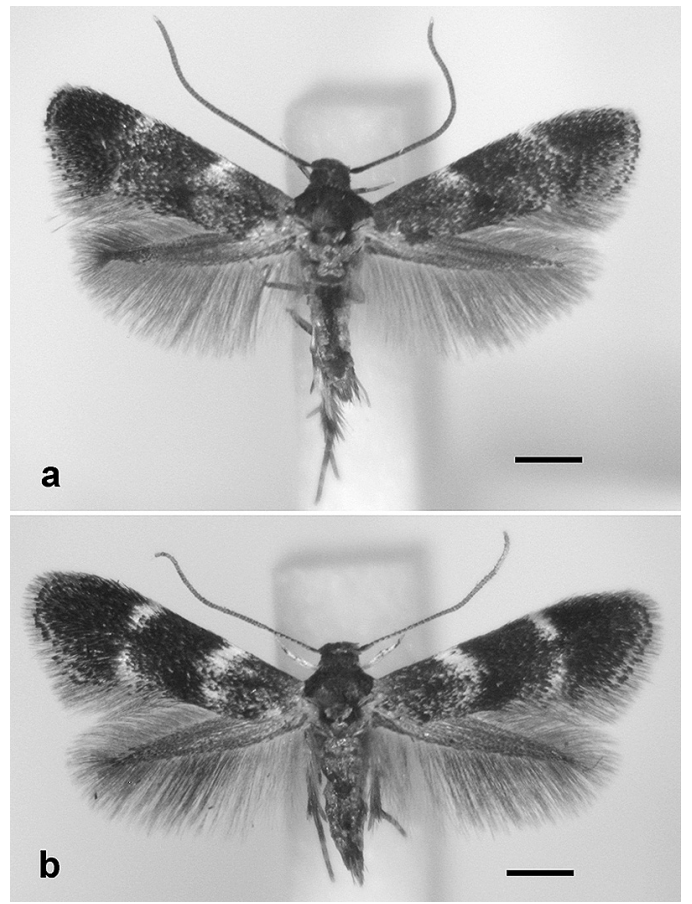

Fig. 10. Elachista sasae Sinev \& Sruoga, moths reared from Sasa senanensis; a. $\partial^{\lambda}$, Hokkaido Univ., Sapporo-si. b. ̊, Miwa, Kosimizu-tyô Scale $1 \mathrm{~mm}$.

Rubeso, Sibetu-tyô, 16.VIII.2001; 1 q, Sôgakudai, Akan-tyô, 21.VII.1994; 1 + , Nukabira-tyô, 14.VII.1959; 11 ๙ 15 \%, Sapporo, Sapporo-si [1

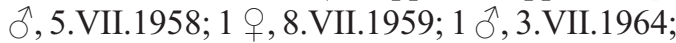
9 ภे 11 ㅇ, em. 9-16.VI.1967, ex Sasa cernua (838); 2 ㅇ, 9.VII.1967; 1 ○, 28.VI.1970) (2 ð 2

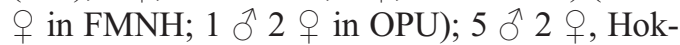
kaidô Univ., Sapporo-si (4 § 2 †, col. 26.V. 1996, em. 11-14.VI.1996, ex Sasa senanensis (00211); 1 ô, col. 3.V.2001, em. 19.V. 2001, ex Sasa senanensis (00419)] (1 $\delta$ in FMNH); 2 त 2 , Moiwa-yama, Sapporo-si, 6.IX.1966; 5 ठิ, Kannon-zawa, Sapporo-si, col. 11.VIII.1998, em. 21-25.VIII.1998, ex Sasa sp. (00304) (1 ô in FMNH); 1 , Hyakumatu-zawa, Sapporo-si, 28.VII.2002, light trap; 2 o 1 , Katuraoka, Otaru-si, 10.VII.2001; 1 ๙ 3 ㅇ, Nagahasi-naebo, Otaru-si [2 9 , col. 30.V.1996, em. 16.VI.1996, ex Sasa sp. (00215); 2 đ, col. 12.VIII.2001, em. 2129.VIII.2001, ex Sasa sp. (00476)]; 1 ㅇ, Hangetu-ko, Kuttyan-tyô, 23.VII.2002, light trap; 1 †, Asahi-onsen, Iwanai-tyô, col. 18.VIII.1997, em. 31.VIII.1997, ex Sasa sp. (00250); 4 đ̂ 1 ㅇ, Pinnesiri, Samani-tyô, em. 13- 


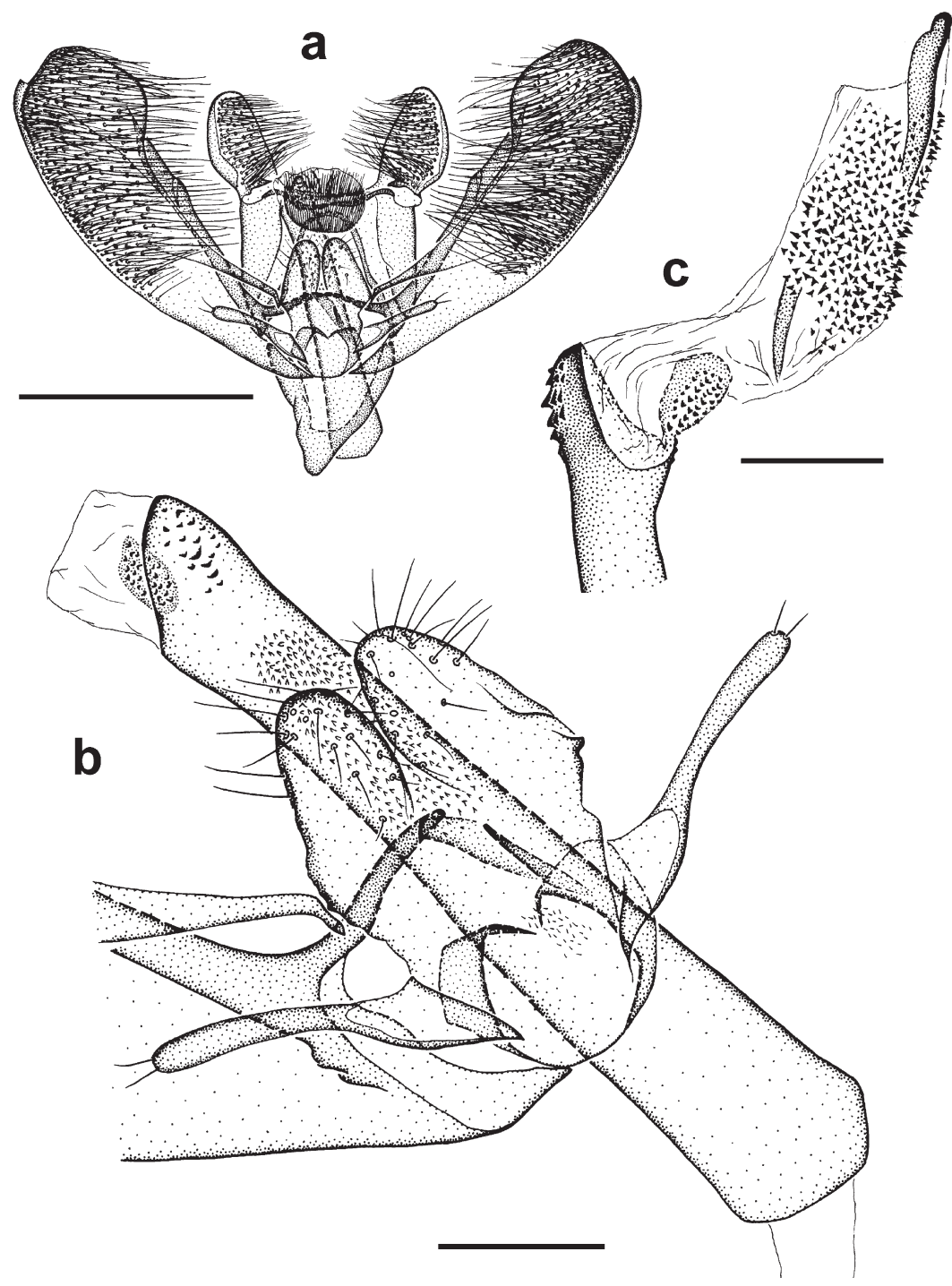

Fig. 11. Elachista sasae Sinev \& Sruoga, ô genitalia. a. Whole genitalia (Hokkaido Univ., Sapporo-si, from Sasa senanensis, slide no. 0338 of K. Sugisima); scale $0.5 \mathrm{~mm}$. b. Magnified view of juxta and cornuti; scale $0.1 \mathrm{~mm}$. c. Cornuti (Tamabaru, Numata-si, from Sasa sp., slide no. 0268 of K. Sugisima); scale 0.1 $\mathrm{mm}$.

14.VI.1996, ex Sasa sp. (00204) (1 § in FMNH; 1 i in OPU); 1 q, Oiwake, Oiwake-tyô, em. 14.VI.1994, ex Sasa sp. (00021); 1 \&, Uenae, Tomakomai-si, 26.VI.1996; 2 गे, Kikonai-tyô, 12.VII.1976. Honsyû: Aomori-ken: 1 ते 2 , Zyôgakura-onsen, Aomori-si, em. 12-15.VI. 1995, ex Sasa sp. (00078). Iwate-ken: 1 ㅇ, Kuriyagawa, 21.VI.1979. Gunma-ken: 3 2 ㅇ, Tamabaru, Numata-si, 22.V.1995, em. 1012.VI.1995, ex Sasa sp. (00075) (1 § in FMNH; $1 \delta 1 q$ in OPU). Saitama-ken: 1 ภ 1 , Hidakasi, em. 24.IV.1994, ex Pleioblastus sp. (00002). Nagano-ken: $1 \hat{\jmath}$, Komuro, Azusagawa-mura, 5.VII.1992 (PCNH). Sizuoka-ken: 3 ก 1 q,

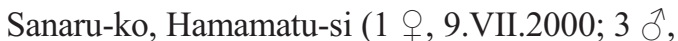
col. 2.VIII.2000, em. 15-17.VIII.2000, ex Pleioblastus sp. (00376) (1 $\lesssim$ in FMNH). Aitiken: 2 đે 1 , Rokusyô-san, Toyota-si, col. 7.IV.1979, em. 24.IV.1979, ex Sasa sp. (2 $\lesssim 1$ ㅇ in OPU); 1 ก̂ 1 9, Asahi-kôgen, Asahi-tyô, col. 9.VII.1999, em. 26-27.VII.1999, ex Sasa sp. (00334). Gihu-ken: 1 đ̃ 2 ๆ, Hirayu-onsen, Kamitakara-mura, em. 5.VI.1995, ex Sasa sp. (00068) (1 q in FMNH). Hyôgo-ken: 1 $\hat{\sigma}$, Hyôno-sen, Sekinomiya-tyô, em. 4.VI.1993, ex Sasa sp.

Redescription. Male (Fig. 10a) and female (Fig. 10b). Forewing length $\widehat{\Im} 4.0-4.7 \mathrm{~mm}$, + 
Fig. 12. Elachista sasae Sinev \& Sruoga,

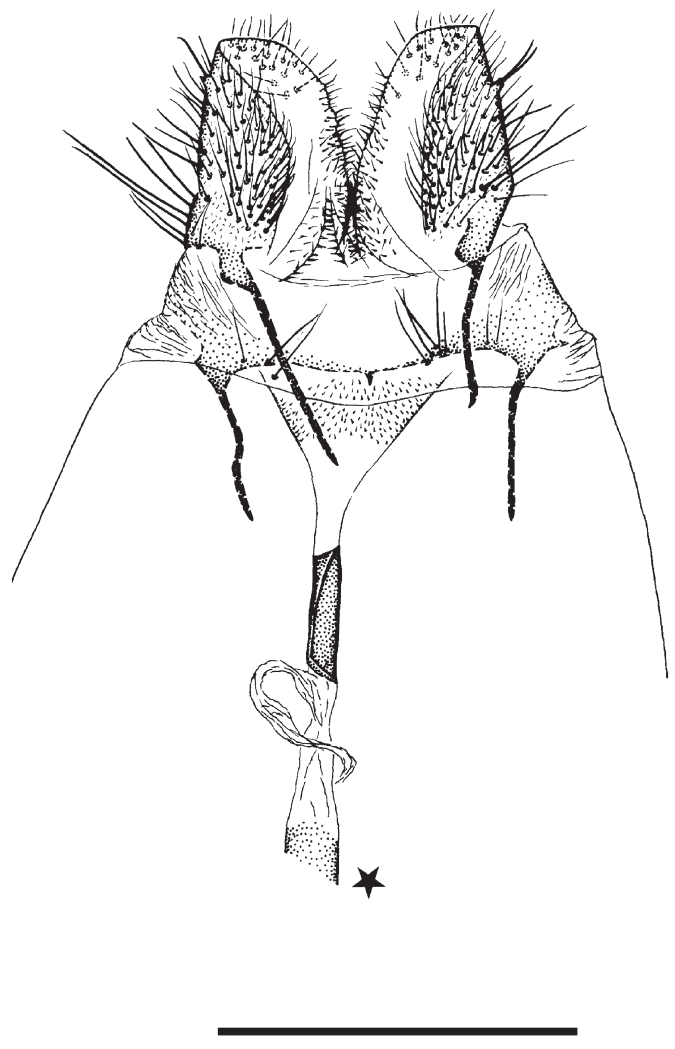

o genitalia (Hokkaido

Univ., Sapporo-si,

reared from Sasa

senanensis), slide no.

0326 of K. Sugisima;

star indicating same

position. Scale $0.5 \mathrm{~mm}$.

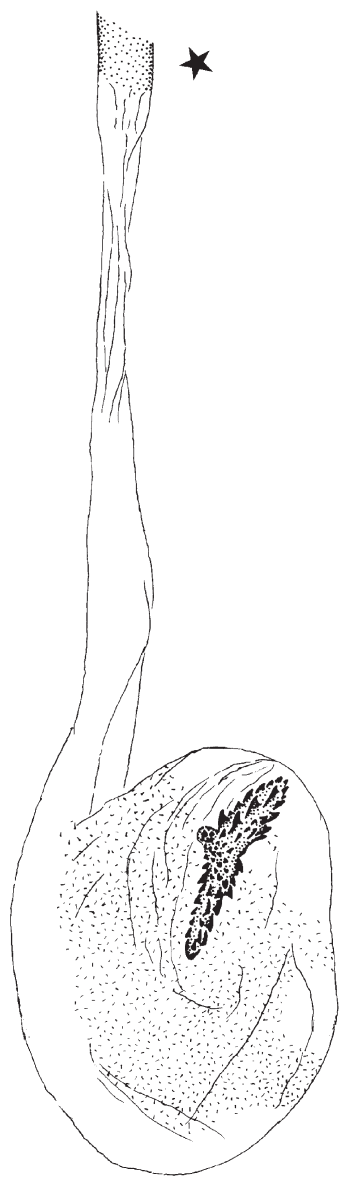

4.6-5.3 mm. Specimens of non-overwintering generations smaller than those of the overwintering generation.

Head sometimes moderately flattened dorsoventrally. Face pale grey-ochreous; vertex and neck tufts dark grey-brownish. Labial palpus more than twice as long as width of head; pale ochreous in most part, outwards dark greyish; complete or incomplete dark greyish rings present near apex of second segment and at base and middle of third one. Thorax and tegula dark greybrownish. Tibiae and tarsi dark greyish outwards, pale ochreous inwards, with fifth segment often entirely pale ochreous; apex of each segment almost always with a pale ochreous ring, except for fourth segment of hind tarsus which never has such a ring; a broad pale ochreous ring present near base of hind tibia. Forewing dark greybrownish, mottled with light greyish bases of scales, with three whitish spots that are some- times reduced considerably: a costal spot at $1 / 3$ being perpendicular to margin or slightly oblique outwards, another costal spot at $2 / 3$ being outwards oblique at various angles, and a tornal spot being opposite to the latter costal spot, most indistinct and smallest; a circular blackish tuft present at $3 / 5$ of fold; cilia dark grey-brownish, with blackish cilia line. Hindwing and cilia dark greybrownish. Seventh and eighth abdominal segments like those of preceding species, but medial incision of sternites shallower.

Wing venation like that of the preceding species, but forewing R3 sometimes slightly distant from base of common stem of R4+5 and M1.

Male genitalia (Fig. 11). Uncus lobes bluntly semi-circular; ventral surface densely covered with long setae, even just near socius; distance between lobes very wide, nearly twice as wide as base of lobe. Tegumen wider than long, parallelsided, with cephalic margin rather strongly 
sclerotised and concave very deeply towards uncus. Gnathos knob large, almost ellipsoidal, wider than long. Valva widening towards apex; costa very strongly sclerotised, with hump at $2 / 3$; ventral margin evenly curving, with apical end forming a blunt spine-like projection. Digitate processes slender, slightly clavate, with two or three short setae around apex. Juxta lobes separated from each other by a deep and narrow cleavage, sub-ovate, approximately 1.5 times longer than wide, with 15 25 short setae scattered; lateral pockets of juxta well developed. Vinculum tapering towards short and blunt saccus. Aedeagus $4 / 5$ the length of the valva, evenly tapering except for apical part that is somewhat swollen and ventrally ornamented with a group of many sub-conical tubercles; apical end ventrally extending into vesica as an oval sclerotised plate bearing many sub-conical tubercles; cornuti (Fig. 13c) composed of a strongly sclerotised rod of 1/6 1/5 length of aedeagus, another much lesssclerotised rod, and a group of numerous teeth surrounding the two rods.

Female genitalia (Fig. 12). Papillae anales semi-elliptical in lateral view, ventrally and laterally with stout setae of various length, and with two extremely stout setae arising from a small projection around caudal 1/3. Apophyses almost equal in length. Ostium opening between seventh and eighth sternites, nearly half the width of eighth sternite. Antrum narrowing towards ductus bursae, weakly sclerotised, with inner surface caudally ornamented with minute spines. Ductus bursae with two colliculi: the caudal one being over 1/10 length of ductus bursae and separated from antrum by a short membranous part, and the cephalic one being somewhat longer and less sclerotised; ductus seminalis branching off from ductus bursae between colliculi. Corpus bursae ovate, with minute spines scattered; signum bluntly lozenge-shaped, with some series of sub-triangular stout teeth.

Distribution. Japan (Hokkaidô, Honsyû; the Russian Far East (Sakhalin) (Sinev \& Sruoga 1995).

Food plants. Two genera of woody Poaceae recognised in this study: Sasa and Pleioblastus. In original description (Sinev \& Sruoga 1995), Sasa kurilensis is recorded as the food plant.

Biology. The description below is based on
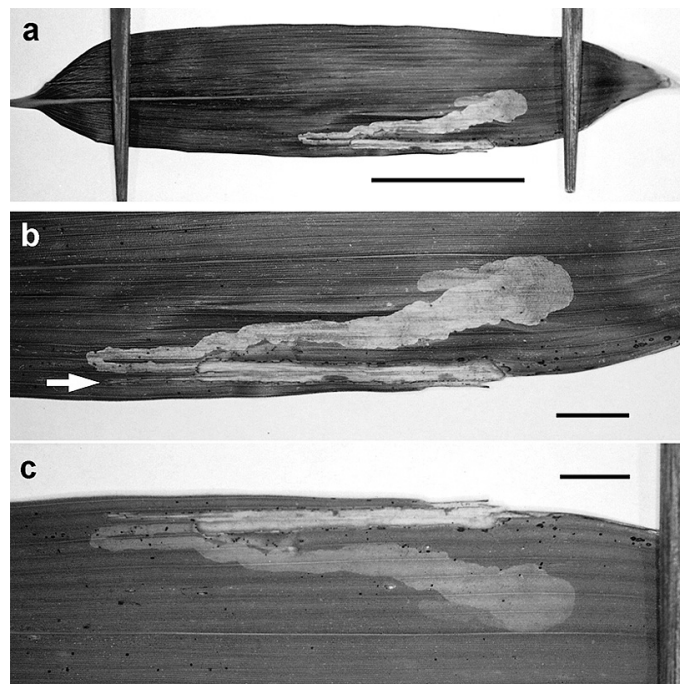

Fig. 13. Elachista sasae Sinev \& Sruoga, larval mines (Hokkaido Univ., Sapporo-si, on leaf of Sasa senanensis). Scale $5 \mathrm{~cm}$ in (a), $1 \mathrm{~cm}$ in (b-c). a. Whole leaf with larval mine. b. Magnified view of mine, upper side; arrow indicating egg-shell. c. Magnified view of mine, underside.

observations at Sapporo-si, where this species is bivoltine: the larva is found from late-July to midAugust and again from October until the following May. The larva is a leaf-miner and reaches its full growth in a single mine. In the mine (Fig. 13) the larva leaves the underside-tissue uneaten and the uneaten tissue survives for some weeks. This larval feeding habit makes the mine translucently whitish in the upperside (Fig. 13b) but opaquely greenish in the underside (Fig. 13c). The mine starts just below the egg-shell, which is adhered to the upper leaf-surface generally of the basal half (Fig. 13b). The early mine is linear, straight or somewhat wavy, and extends towards the apex of the leaf for several centimeters being restricted within the area between the adjoining strong veins. Then the linear mine U-turns beyond a strong vein and extends towards the base in a similar way or somewhat widening. And finally, soon after taking the second U-turn, it abruptly broadens and becomes a large blotch, extending on the whole towards the apex of the leaf. The large blotch-mine seems to broaden beyond strong veins easily. Excrements are scattered sparsely inside the mine but fairly indistinct. In the overwintering generation, the first U-turn 


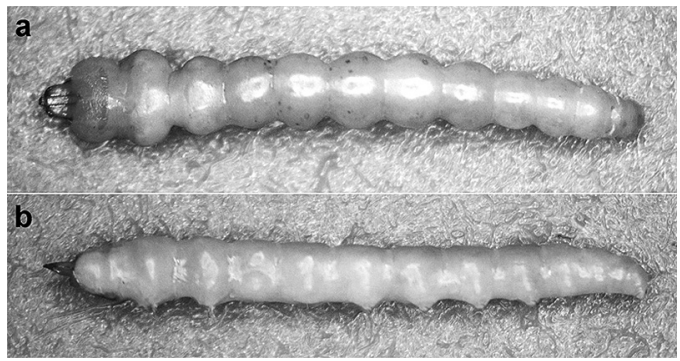

Fig. 14. Elachista sasae Sinev \& Sruoga, larva (Hokkaido Univ., Sapporo-si, from Sasa senanensis). a.

Dorsal view. b. Lateral view.

usually occurs in autumn, the second one occurs in the following spring, and the linear mine is observed to extend for not a short while after the end of the larval hibernation.

The larva (Fig. 14) is whitish but turning pale purple-brownish in case of pupation, with the head and the prothoracic shields dark brownish. The full-grown larva cuts the upperside-epidermis and leaves the mine to pupate. In rearing condition, pupation takes place on both the angled and non-angled places, in a "cocoon" of very rough transverse series of silk filaments. The pupa (Fig. 15) is supported by a silk girdle and the cremaster, brownish, with the dorsal ridge and a pair of more distinct dorso-lateral ridges on the abdomen. The adult is often found running or turn-dancing on the upperside of the food-leaf, in early-July and again in September. It is occasionally attracted to light.

It is probable that one more non-overwintering generation is present in warmer districts and that the non-overwintering generation is absent in colder ones.

Remarks. Sinev \& Sruoga (1995) described this species on the basis of the male holotype and three female paratypes collected at Sakhalin. Many rearing series of the leaf-miners on woody Poaceae in Japan show that the drawing of the female genitalia in the original description was attributed not to a species comprising the holotype of $E$. sasae, but to another species comprising the holotype of E. planicara treated below. This means that the type series of E. sasae is a mixture of two species and that the females designated as the paratypes of $E$. sasae are not $E$. sasae but $E$. planicara. Therefore, the female of $E$. sasae is described for the first time in this paper. The adults

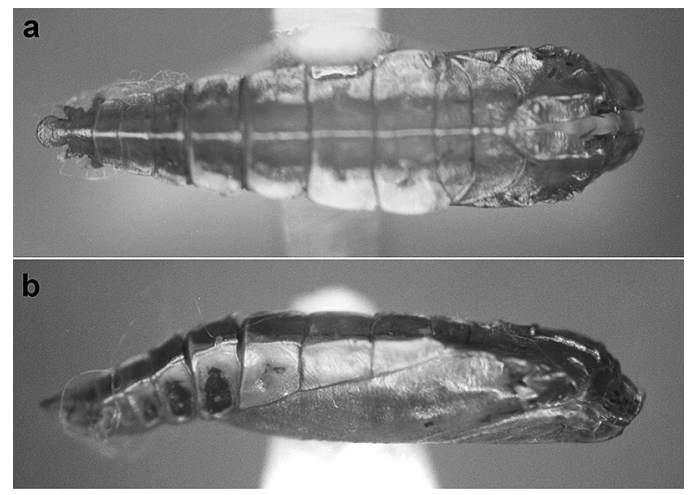

Fig. 15. Elachista sasae Sinev \& Sruoga, pupa (Hokkaido Univ., Sapporo-si, from Sasa senanensis). a. Dorsal view. b. Lateral view.

of E. sasae and E. planicara are quite similar in appearance, but easily distinguished from each other by features of the genitalia and immature stages. Discrimination of these species is given in the redescription and remarks of the next species.

\subsection{Elachista planicara Kaila, 1998 (Figs. 16-24)}

Elachista sasae Sinev \& Sruoga, 1995: 130-132 (in part; see Remarks); Sruoga (2004): 5 (in part; see Remarks).

Elachista planicara Kaila, 1998: 57-59.

Specimens examined. Hokkaidô: 1 을 Wakkanai-si, 31.VII.1958; 1 ふૈ, Rebun-tyô, 1.VIII.1958; 1 †, Menasibetu, Toyotomi-tyô, 24.VIII.1993; 3 $\hat{\jmath}$, Minamisimonuma, Horonobe-tyô, 22. VII. 1993 (1 $\hat{\sigma}$ in FMNH); $1 \hat{\jmath}$, Toikanbetu, Nakagawa-tyô, 12.VIII.1965; 1 ก, Hokuto, Kosimizu-tyô, 29.VII.1992, light trap; 4 đิ 2 , Miwa, Kosimizu-tyô (1 đ̊, 17.VII.1993, light trap; 3 ๙ 2 , 13-19.VII.1999) (1 $\lesssim 1$ in FMNH); 1 กิ 1 ㅇ, Kenebetu, Nakasibetu-tyô, 27.VII.1995; 1 đે, Rubeso, Sibetu-tyô, 16.VIII. 2001; 1 đ̂ 1 q, Sibetu, Sibetu-tyô, 14.VIII.2001; 1 ○े 1 ㅇ, Yûbari-dake (1 §, 22.VII.1962; 1 ㅇ, 10.VIII.1966); 6 đ̃, Takinosita, Kuriyama-tyô, light trap (4 $\hat{\jmath}, 19$.VII.1995; $2 \hat{\jmath}, 13$. VII.1998) (1 $\widehat{\partial}$ in FMNH); 1 1 \% , Tappu-yama, Iwamizawasi, 27.VII.2002, light trap; 2 , Oiwake, Oiwaketyô, em. 25.VI.1994, ex Sasa sp. (00021); 2 ô, Eniwa-keikoku, Eniwa-si, 31.VII.2001, light trap; $2 \hat{\jmath} 3$ + , Nopporo, Ebetu-si [1 $\curvearrowright 1$, em. 6- 
7.VI.1994, ex Sasa sp. (00013); 1 \ॅ2 5.V.1996, em. 12-16.VI.1996, ex Sasa sp. (00195)]; 20 ^ 19 q, Hokkaido Univ., Sapporosi [2 ᄋ, col. 25.V.1996, em. 30.VI-1.VII.1996, ex Sasa senanensis (00210); 20 ते 16 ㅇ, col. 3.V.2001, em. 30.V-9.VI.2001, ex Sasa senanensis (00419)] ( 4 今 4 ㅇ in FMNH; 3 त 3 q in OPU); 1 त 1 क, Hituzigaoka, Sapporo-si, 23.VII.2002, light trap; 4 ऽ 3 , Kannon-zawa, Sapporo-si [1 + , 2.VIII.1993; 4 ते 2 ㅇ, col. 17.V.2002, em. 13-19.VI.2002, ex Sasa sp. (00565)]; 1 ô, Hyakumatu-zawa, Sapporo-si, 28.VII.2002, light trap; 3 ô, Usubetu, Sapporosi, col. 17.V.2002, em. 14-15.VI.2002, ex Sasa sp. (00570); 2 ^ 1 q, Katuraoka, Otaru-si (1 ^ 1 ㅇ, 14.VIII.2000; 1 ふ, 10.VII.2001); 2 , Naebo, Nagahasi, Otaru-si, em. 3-5.VII. 1996, ex Sasa sp. (00214); 1 q, Yobetu-gawa, Syakotan-tyô, 21.VII.1993; 1 ô, Hangetu-ko, Kuttyan-tyô, 23.VII.2002, light trap; 1 \%, Higasikawa, Kuromatunai-tyô, 22.VII.1997, light trap; 1 ઈ,, Kariba-yama, Simamaki-mura, 19 23.VII.1972; 1 ․ Takinomati, Sôbetu-tyô, 5.VIII.1993; 1 ㅇ, Gamusi, Atusabu-tyô, 12.VII.1958. Honsyû: Aomori-ken: 1 ふָ, Sukayu-onsen, Aomori-si, 31.VII.1970; 1 q, Zyôgakura-onsen, Aomori-si, em. 30.VI.1995, ex Sasa sp. (00078). Gunmaken: 5 đิ 4 ㅇ, Tamabaru, Numata-si, col. 22.V. 1995, em. 21-25.VI.1995, ex Sasa sp. (00074) (1

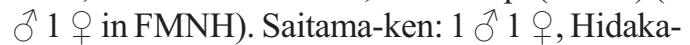
si, em. 13.V.1994, ex Pleioblastus sp. (00002).

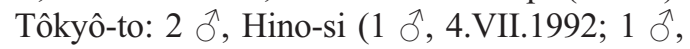
8.VI.1997). Nagano-ken: 4 ๙ิ 6 9, Komuro,

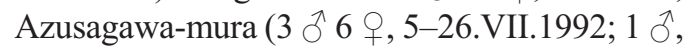
4.VII.1993) (4 ते 6 क in $\mathrm{PCNH}$ ); 4 ते 2 \%, Karasugawa-dani, 18-23.VII.1982 (4 ㄱ 2 ㅇ in PCNH); 1 ô, Hario, Asahi-mura, 15.VII.1984 (1 $\widehat{\jmath}$ in PCNH); 1 ऽ, Ôsirakawa, Azumi-mura, 5.VIII.1995 ( 1 § in PCNH); 1 ๙ै, Simasima-dani, Azumi-mura, 12.VIII.1997 (1 $\lesssim$ in PCNH). Aitiken: 2 + , Asahi-kôgen, Asahi-tyô, 9.VII.1999; 1 ऽิ 1 , Uradani (900m), Kitasidara-gun, 28.VI-

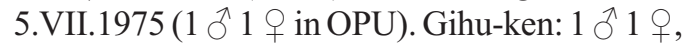
Hirugano, Syôkawa-mura, col. 13.V.1995, em. 5.VII.1995, ex Sasa sp. (00067); 1 q, Hirayuonsen, Kamitakara-mura, em. 25.VI.1995, ex Sasa sp. (00068). Ôsaka-fu: 6 §ิ 6 †, Aokaiyama, Toyono-tyô, col. 20.II.2001, em. 1017.IV.2001, ex Pleioblastus sp. (00414) (1 1 \ 1 ㅇ in FMNH). Hyôgo-ken: 1 $\widehat{\jmath}$, Hukuoka,

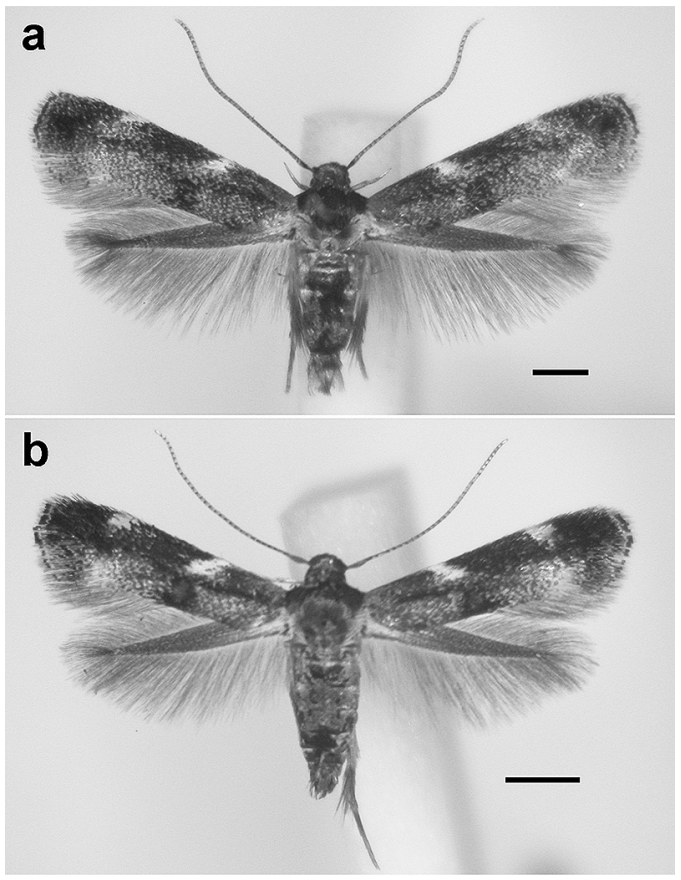

Fig. 16. Elachista planicara Kaila, moths reared from Sasa senanensis at Hokkaido Univ., Sapporo-si. a. ô. b. . . Scale $1 \mathrm{~mm}$.

Muraoka-tyô, em. 16.V.1996, ex Sasa sp.; 1 ô, Hyôno-sen, Onsen-tyô, em. 4.VI.1995, ex Sasa sp. (00063); 2 q, Hyôno-sen, Sekinomiya-tyô, em. 21-25.VI.1993, ex Sasa sp. Tottori-ken: $1 \hat{\jmath}$, Kidiyama, Misasa-tyô, em. 18.VI.1993, ex Carex morrowii. Hirosima-ken: 3 ๙ 2 q, Tyôzyahara, Geihoku-tyô, 10.VII.2001. Sikoku: Ehime-ken: 1 ô, Okawamine, Mikawa-mura, 8.VII.2001. Kyûsyû: Hukuoka-ken: 5 त 3 ㅇ, Hiko-san, col.

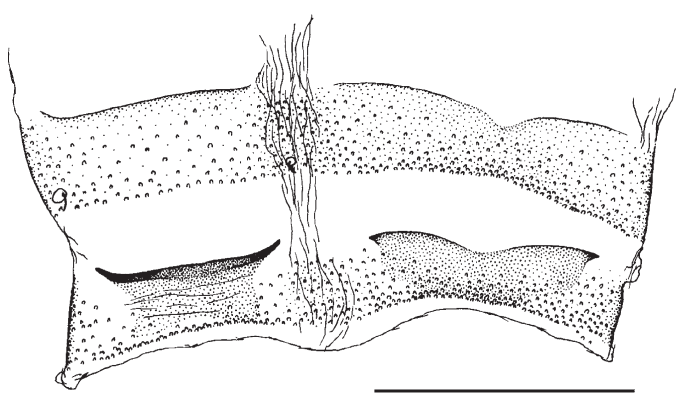

Fig. 17. Elachista planicara Kaila, ô terminal segments of non-genital abdomen, tergite to left, sternite to right (Nopporo, Ebetu-si, from Sasa sp.), slide no. 0307 of K. Sugisima. Scale $0.5 \mathrm{~mm}$. 


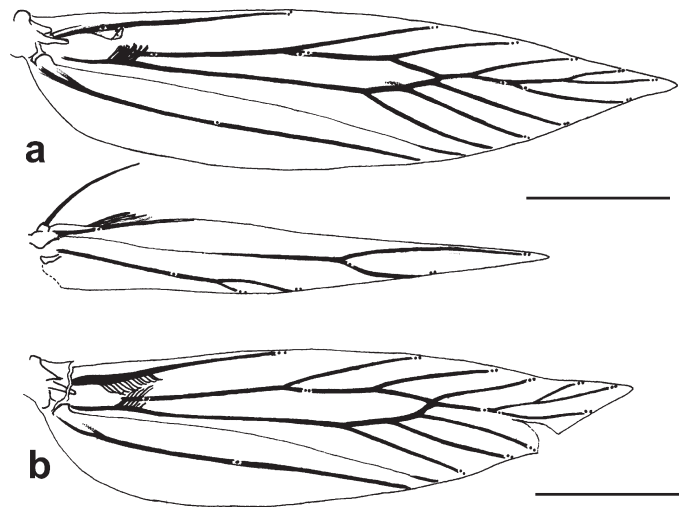

Fig. 18. Elachista planicara Kaila, wing venations; scale $1 \mathrm{~mm}$. a. $\widehat{o}$ (Takinosita, Kuriyama-tyô slide no. 0585 of K. Sugisima). b. ㅇ (Nopporo, Ebetu-si, from Sasa sp., slide no. 0588 of K. Sugisima).

30.III.1996, em. 26.V-3.VI.1996, ex Sasamorpha borealis (00178) (1 $\lesssim$ in FMNH).

Redescription. Male (Fig. 16a) and female (Fig. 16b). Forewing length ô 4.0-5.2 mm, of 4.0-5.0 $\mathrm{mm}$. The adult moths are similar in appearance to $E$. sasae, while being generally more slender-winged and lighter-coloured. Therefore the features of the adult appearance are omitted from the redescription here, except for those that may serve for separation of the two species.

Head and thorax moderately to considerably flattened dorso-ventrally, while those of E. sasae are at most moderately flattened. Eyes of male large in comparison with head, while it is relatively small in the male of E. sasae. Hind tarsus with a pale ochreous ring at apex of all segments, including fourth one where such a ring never appears in E. sasae. Costal spot at 1/3 of forewing generally narrower and much more oblique than that of E. sasae; another costal spot present beyond $7 / 10$ and always distant from tornal spot, while that of E. sasae is present at 2/3 and sometimes reaches the tornal spot. Eighth abdominal tergite with a sclerotised ridge almost along cephalic margin; a similar but less-developed ridge present in seventh tergite; these ridges less curved and weaker than those of E. sasae; the seventh and eighth sternites with the cephalic margin slightly concave around the middle (Fig. 17).

Wing venation (Fig. 18) similar to that of preceding two species, but sometimes R3 of forewing distinctly stalked with common stem of $\mathrm{R} 4+5$ and $\mathrm{M} 1$.

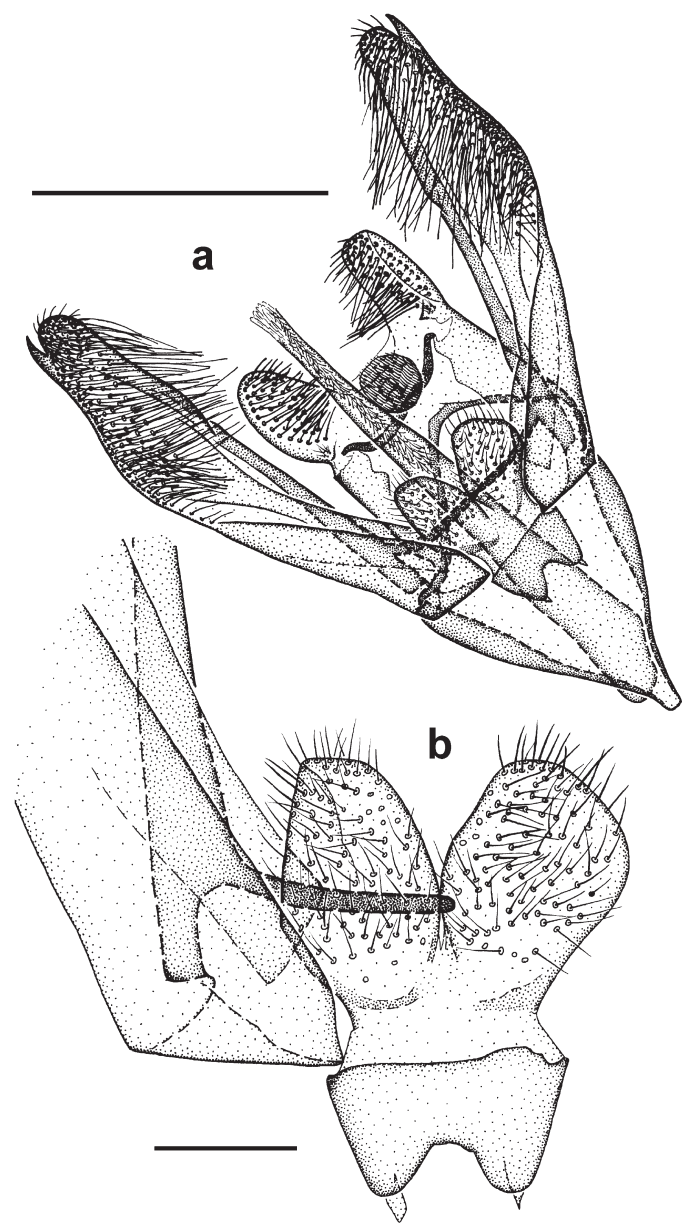

Fig. 19. Elachista planicara Kaila, ồ genitalia (Nopporo, Ebetu-si, from Sasa sp., slide no. 0307 of K. Sugisima). a. Whole genitalia; scale $0.5 \mathrm{~mm}$. b. Magnified view of juxta; scale $0.1 \mathrm{~mm}$.

Male genitalia (Figs. 19-20). Uncus lobes bluntly semi-circular, with inner margin nearly straight; setae on ventral surface long, densely scattered; distance between lobes as wide as base of lobe. Tegumen as long as wide, with cephalic margin strongly sclerotised and concave moderately deeply towards uncus. Gnathos knob spherical. Valvae slender, tightly connected with vinculum to an extent of loss of mobility, with valva process weakly sclerotised for species of subgenus Elachista; dorsal margin almost straight, near apex with a weak incision that may indicate the border between the costa and cucullus (if this interpretation is right, the costa occupies basal 9/10 of the dorsal area of the valva 


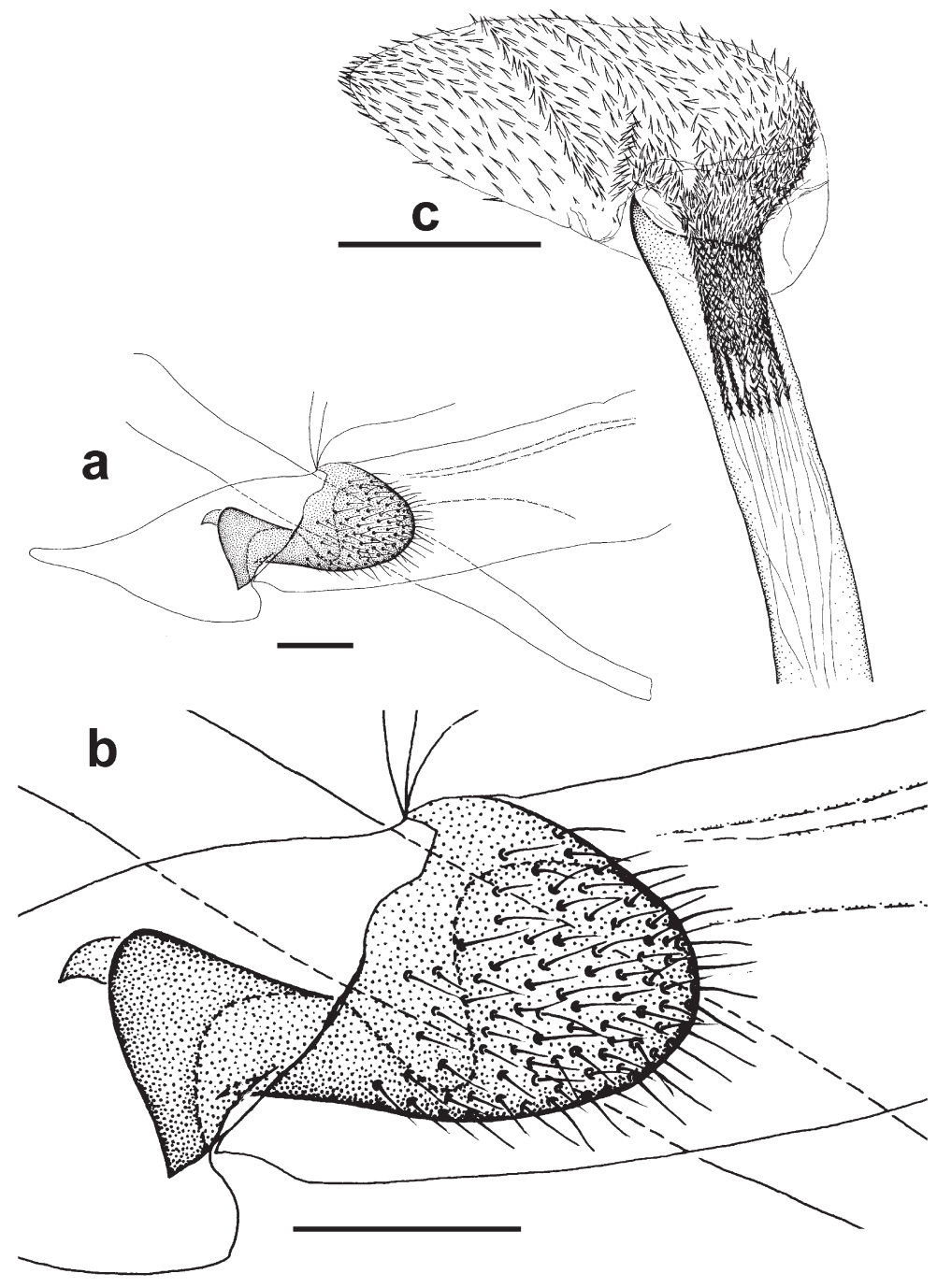

Fig. 20. Elachista planicara Kaila, ồ genitalia, scale 0.1 $\mathrm{mm}$. a. Lateral view of area around juxta (Takinosita, Kuriyama-tyô slide no. 0865 of K. Sugisima). b. Lateral view of juxta, magnified (slide no. 0865 of K. Sugisima). c. Cornuti (Sapporo, Sapporosi, from Sasa puniculata, slide no. 0235 of $\mathrm{K}$. Sugisima). and the cucullus is considerably reduced for Elachista species); ventral margin nearly parallel to costal margin in basal $3 / 5$, gradually approaching costa in distal part, with distal end forming a conspicuous sub-conical thorn; costa very strongly sclerotised, divided into almost straight basal part and slightly convex distal part by a suture around 3/4. Digitate processes absent. Juxta (Figs. 19b, 20b) lobes very bluntly rhomboid, with short setae scattered on ventral and lateral surface; ventro-cephalic part of juxta dorsocephalically concave deeply, forming a sac which is distally bilobed and has a small crest-like projection on the top of each lobe. Vinculum long, well-developed, tapering towards short saccus.
Aedeagus slender, tapering towards apex, and as long as or slightly longer than valva; vesica (Fig. 20c) with numerous long and thin teeth.

Female genitalia (Fig. 21). Papillae anales semi-elliptical in lateral view, ornamented with stout setae of various length ventrally and laterally; setae on latero-basal part distinctly longer and more robust. Apophyses of almost equal length. Ostium between seventh and eighth sternites, nearly half the width of eighth segment. Antrum very large, wine-glass-shaped, heavily sclerotised, longer than apophyses, with inner surface smooth. Colliculum as long as antrum, occupying cephalic half of ductus bursae. Corpus bursae pear-shaped, indistinctly divided into 

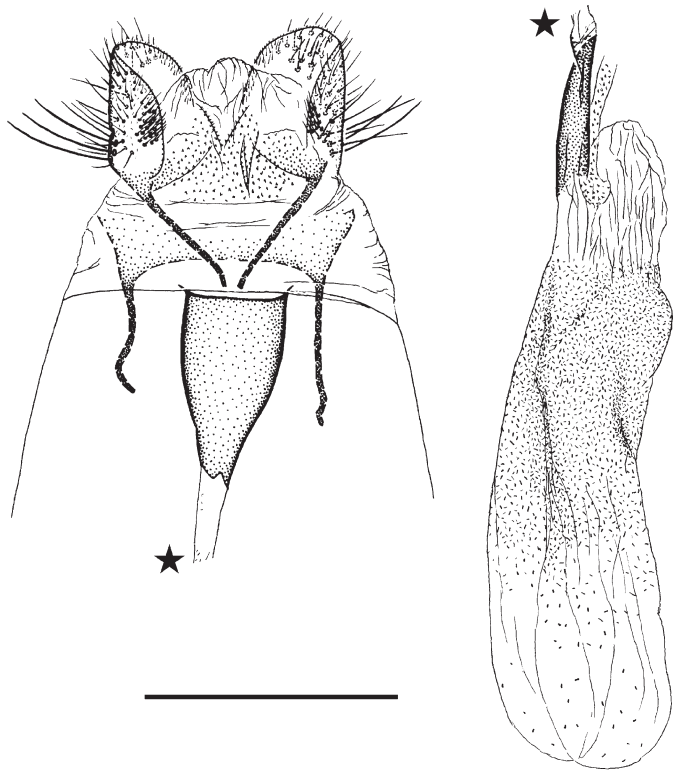

Fig. 21. Elachista planicara Kaila, o genitalia (Nopporo, Ebetu-si, from Sasa sp., slide no. 0306 of K. Sugisima); scale $0.5 \mathrm{~mm}$.

finely spined cephalic $4 / 5$ and remaining $1 / 5$ being longitudinally folded to various extent; ductus seminalis branching off from the caudal part of corpus bursae.

Distribution. Japan (Hokkaidô, Honsyû, Sikoku, Kyûsyû ; Far Eastern Russia (Kuril) (Kaila 1998).

Food plants. Three genera of woody Poaceae are recognised: Sasa, Sasamorpha, and Pleioblastus. One male is labelled as having been reared from a leaf-miner on Carex morrowii, but this record should be verified.

Biology. The description below is based on observations in Sapporo-si, where this species is univoltine: the larva is observed from late September until the following May. The larva is a leaf-miner and reaches its full growth in a single mine, which contains little tissue left uneaten inside. The mine (Fig. 22) tends to be found near the edge of the leaf rather than on the medial areas. It starts just below the egg-shell that is adhered to the upper-surface of the leaf (Fig. 22b). The autumn mine is wavy-linear with the width gradually increasing, usually a few centimeters in length, and often restricted within the area between adjoining strong veins. After hibernation, the mine becomes a blotch that is several centime-

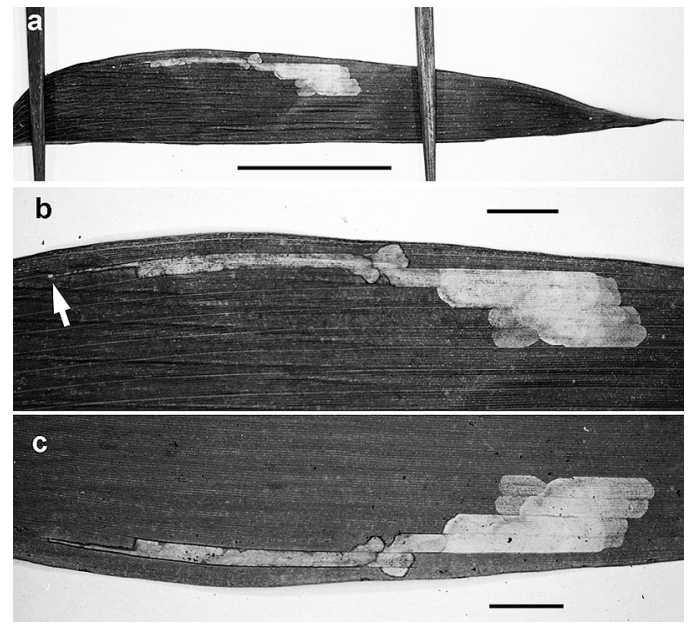

Fig. 22. Elachista planicara Kaila, larval mines (Hokkaido Univ., Sapporo-si, on leaf of Sasa senanensis); scale line $5 \mathrm{~cm}$ for $1 \mathrm{~cm}$ for others. a. Whole leaf with larval mine. b. Magnified view of mine, upperside; arrow indicating egg-shell. c. Magnified view of mine, underside.

ters in length and occupies the area between a few strong veins. Excrements are inside the mine, roughly gathered behind the larva in autumn but scattered near the margin of the mine in spring.

The larva (Fig. 23) is fairly flat, whitish, with the head and prothoracic shields black-brownish.

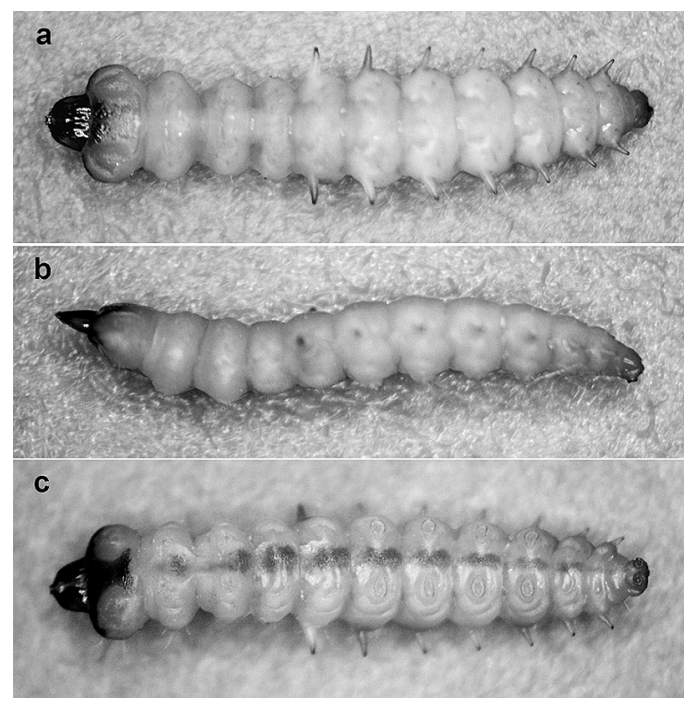

Fig. 23. Elachista planicara Kaila, larva (Hokkaido Univ., Sapporo-si, from Sasa senanensis). a. Dorsal view. b. Lateral view. c. Ventral view. 

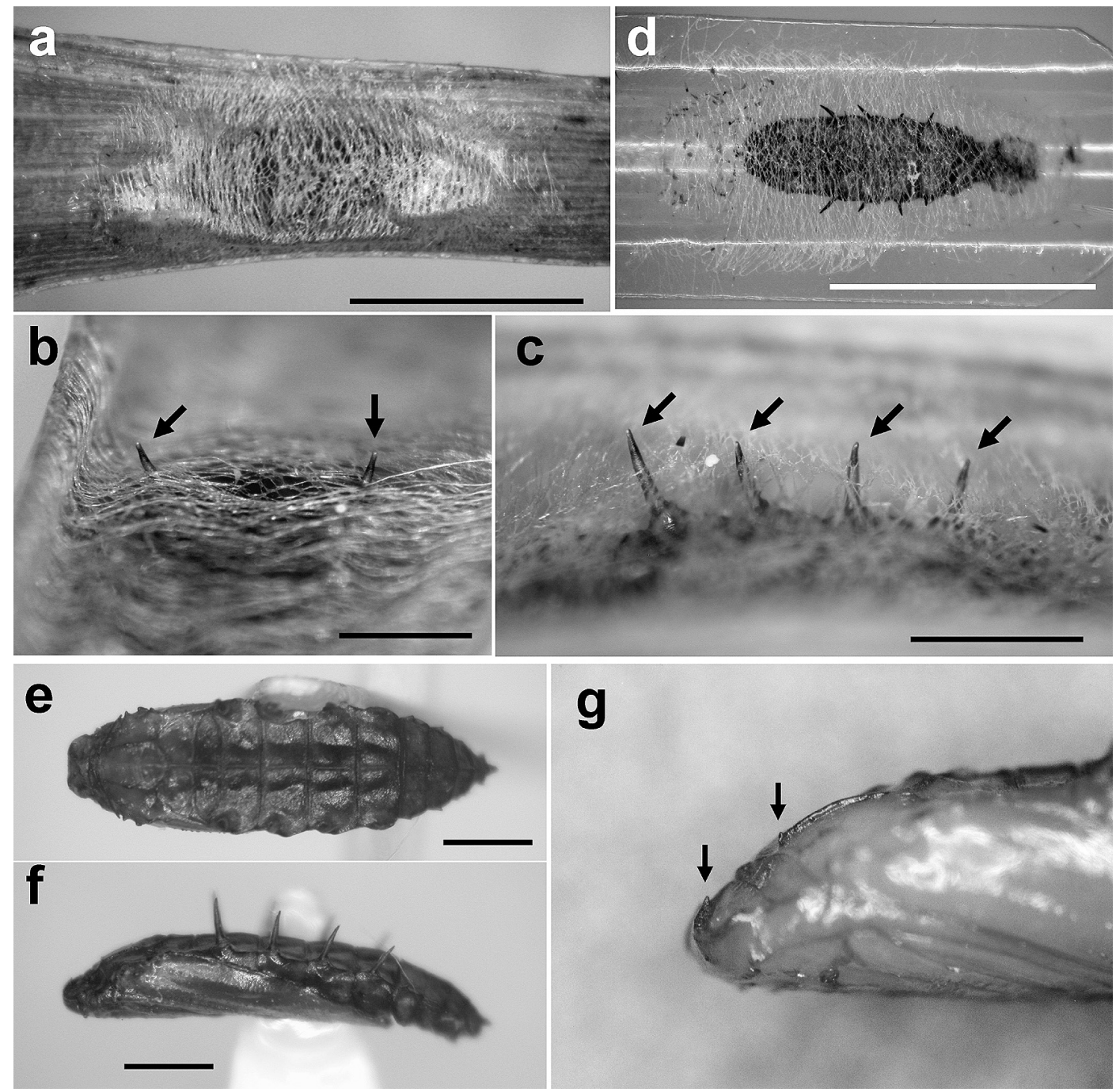

Fig. 24. Elachista planicara Kaila, cocoon and pupa (a-d: Kannon-zawa, Sapporo-si, from Sasa sp.: e-g: Hokkaido Univ., Sapporo-si, from Sasa senanensis). Scale $5 \mathrm{~mm}$ in (a-b) and $1 \mathrm{~mm}$ in (c-g). a. Cocoon with pupa inside, constructed on food-leaf. b. Spiracular projections appearing through the silk-roof indicated by arrows, caudal view. c. Lateral view. d. Cocoon with pupa inside, made on surface of plastic rearing cage, showing position of pupa. e. Pupa, dorsal view. f. Pupa, lateral view. g. Spines on pupal vertex and mesothorax indicated by arrows.

Its abdomen has paired tubular projections prominently extending laterally in the second to eighth segments. The projection has the spiracle at the apex and becomes shorter as backwards. In rearing condition, pupation takes place on the angle of the rearing cage or leaf, beneath the tent-like cocoon (Fig. 24a, d) composed of densely spun transverse silk filaments.

The pupa (Fig. 24e-g) is flat spindle-shaped, with a pair of dorso-lateral ridges and a weak dor- sal ridge on the abdomen. Each of the second to fifth abdominal segment has a pair of very long tubular projections, which arise from the dorsolateral ridges and prominently extend sub-dorsally thorough the roof of the cocoon and have the spiracle at the apex (Fig. 24 b-c). Vertex has a pair of short spines, and the mesonotum also has a pair of spines (Fig. 24g). The pupa is supported by the cremaster and the spiracular-projections; the silkgirdle is absent. The adult occurs from mid-July 
to the beginning of August. It is sometimes found running on the leaf of the food plant, and is attracted to lights remarkably frequently for Elachista.

In other districts of Japan, this species is probably univoltine, spending the summer as an egg, and hibernating as a larva.

Remarks. Kaila (1998) described this species on the basis of two females collected at Kuril. Sruoga (2004) synonymised E. planicara under E. sasae, stating that the original description and illustrations of E. planicara agree completely with the type specimens of E. sasae. As mentioned in the remarks of the preceding species, the female paratypes of $E$. sasae are not conspecific with the holotype of $E$. sasae but with that of $E$. planicara. In this study, it is verified that the holotype of E. sasae and that of E. planicara belong to different species. Consequently, both E. sasae and $E$. planicara are valid names.

In appearance of adult moths, E. planicara is very similar to $E$. sasae. Without dissection, the colouration of the fourth hind tarsal segment is probably the best feature for separating the adults of the two species: an ochreous ring is present at apex in E. planicara but absent in E. sasae. The second best diagnostic is thickness of the thorax: it is considerably flattened dorso-ventrally in $E$. planicara but at most moderately in E. sasae. They can readily be separated in features of the larval mine, larva, and pupa. The mine of $E$. sasae (Fig. 13) seems opaquely greenish below the leaf because of the underside-tissue left uneaten, while that of E. planicara (Fig. 22) has little tissue remaining inside. The larva and pupa of $E$. planicara have paired long tubular projections on abdominal segments (Figs. 23-24), but such projections are absent in E. sasae (Figs. 14-15).

\section{Discussion}

\subsection{Position of Elachista canis and E. sasae}

Parenti (1983) stated that there were no plainly close relatives of Elachista canis among congeneric species known at that time, emphasising its peculiarity in the structure of the genitalia. Later, Sinev \& Sruoga (1995) referred this species as the close relative of E. sasae, though they did not mention the characters indicating the close affinities of the two species or their phylogenetic positions within the genus.

The aedeagus of $E$. canis (Figs. 2, 6b) and $E$. sasae (Fig. 11b-c) share the following characters: a group of tubercles present at the apex ventrally (square 2 in Fig. 25), and the vesica with a large sclerotised rod and a group of numerous spines (square 3 in Fig. 25). No other species has these characters, which supports the view that the two species are closely related to each other.

Elachista canis and E. sasae have the hindwing without the veins M2 and M3 (Fig. 5; square 1 in Fig. 25) and the cephalic margin of their tegumen is deeply concave towards the uncus (Figs. 6a and 11a; square 5 in Fig. 25). Based on these characters, the current classification of Elachistidae (Kaila 1999a, 1999b) would suggest the placement of these two species in the clade forming the sister-clade of E. bifasciella-group, i.e. the clade comprising the E. praelineata-, E. saccharella-, E. freyerella-groups. Elachista canis and E. sasae share the following characters that are supposedly ancestral within the clade: the non-twisted uncus lobes covered with dense long setae; the dorsally projected lateral pockets of the juxta; the antrum weakly sclerotised and separated from the colliculum by a membranous part. In addition, the male genitalia of the two species, except for the aedeagus, are of rather typical structures of E. bifasciella-group, and the sclerotised rod on vesica can be interpreted as a derived form of the spine observed on the vesica of some species of $E$. bifasciella-group. Therefore, it is conceivable that E. canis and E. sasae together form one of the basal lineages within the sister clade of the E. bifasciella-group.

\subsection{Position of Elachista planicara}

Kaila (1998) inferred that Elachista planicara was closely related to E. heteroplaca Meyrick and E. lorigera (Meyrick) and belonged to a clade comprising the species previously placed in the genera Dicranoctetes Braun, Eupneusta Bradley, and Cosmiotes Clemens, as well as E. heteroplaca and E. lorigera. At that time, the female adult alone was known for E. planicara, and this inference was based only on the characters de- 


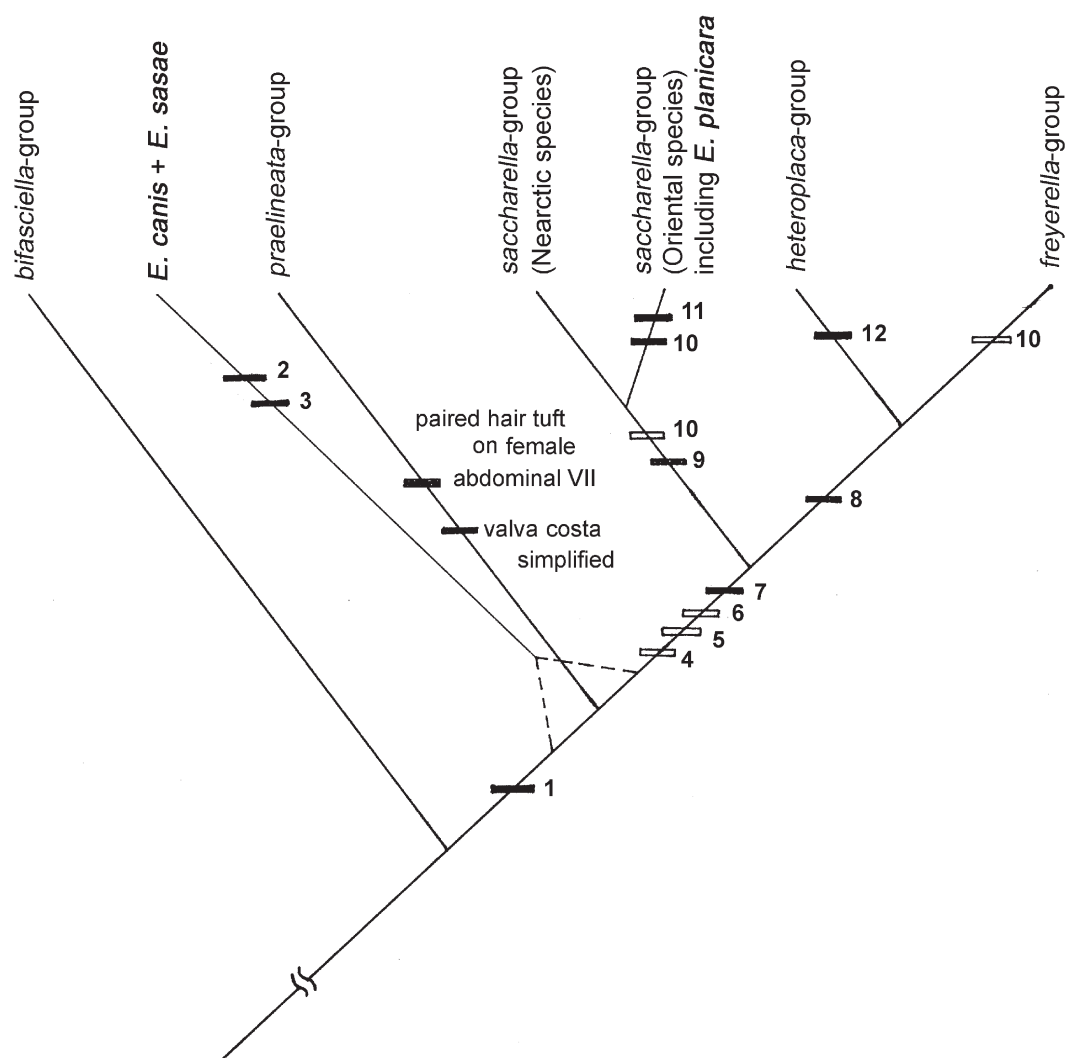

Fig. 25. Presumable phylogenetic positions of $E$. canis, E. sasae, and E. planicara. Filled squares indicating derived characters completely shared by the species within the clade; blank squares indicating derived characters polymorphic within the clade. Numbers on sides of squares corresponding with the character numbers as follows: 1 = hindwing without $\mathrm{M} 2$ and M3; 2 = aedeagus apically with a patch of tubercles; 3 = vesica with a sclerotised rod; $4=$ valva immobile because of its tight connection with vinculum; $5=$ tegumen with cephalic margin deeply concave towards uncus; $6=$ pupal vertex with paired spines; $7=$ pupal abdomen less mobile and bearing projecting spiracles; $8=$ uncus twisted basally; $9=$ pupal spiracle projections very long; $10=$ juxta sac-shaped; 11 = larval spiracles projecting; 12 = valva apically dilated and bilobed.

tectable in the female adult: the dorso-ventrally flattened head, the large wine-glass-shaped antrum, and the ostium situated between the seventh and eighth sternites. In Kaila (1999a, b) later papers on the phylogeny and classification within Elachistidae, the above-mentioned clade is equal to the clade composed of E. saccharella- and $E$. freyerella-group. The clade was supported by several characters of the male genitalia and pupa, unknown for E. planicara until this paper. Therefore, the phylogenetic position of E. planicara is reexamined on the basis of the features of the male and immature stages. It should be noted that another monophyletic species-group, the $E$. heteroplaca-group, can be recognised within the clade. This group is defined by the uncus lobes being twisted basally (square 8 in Fig. 25) and round apically, the basal arms of gnathos being strongly melanised, the very large juxta lobes bearing scale-like setae, and the valva being distally dilated and bilobed (square 12 in Fig. 25), and contains E. albrechti Kaila, E. heteroplaca Meyrick, E. lorigera Meyrick, and many other undescribed species from the Oriental region (Kaila, unpublished data; Sugisima, unpublished data). At present, it seems relevant to examine 
whether E. planicara matches either of $E$. saccharella-, E. heteroplaca-, or E. freyerellagroup.

With regard to the male genitalia, $E$. planicara has remarkable similarities with several species of the clade. The median plate of the juxta is dorso-cephalically concave and forms a distinct sac (Figs. 19b, 20a-b; square 10 in Fig. $25)$, and the valva is tightly connected with the vinculum to an extent of loss of mobility (Fig. 19a; square 4 in Fig. 25). These characters are derived ones within the Elachista species, and shared by species such as E. solena Bradley and E. griseola Diakonoff of the E. saccharellagroup as well as almost all species of $E$. freyerella-group. Among these species, E. griseola alone shares with E. planicara the cephalically bilobed sac of the juxta. The monophyly of the $E$. freyerella-group is supported by the uncus lobes which are basally twisted and apically pointed. Those of E. planicara are basally little-twisted and apically rounded. The valva of E. planicara is neither widened nor bifurcate distally as in the representatives of the $E$. heteroplaca-group. Therefore, on the basis of the male genitalia, $E$. planicara could be assigned to E. saccharellagroup, with the most significant similarities with E. griseola.

With respect to pupal structures, the clade is supported by the following characters: the vertex with a pair of spines (square 6 in Fig. 25), the abdomen with spiracular projections (square 7 in Fig. 25), and the abdomen with the fourth and fifth segments being immobile (square 7 in Fig. 25). The pupa of E. planicara (Fig. $24 \mathrm{e}-\mathrm{g}$ ) has all these characters, except for the fifth abdominal segment being mobile in E. planicara. The spiracular projections and less-mobile joints of the abdomen are sometimes observed outside the clade: e.g. E. nitensella Sinev et Sruoga of the $E$. gleichenella-group and E. coloratella $\mathrm{Sinev}$ et Sruoga of the E. tetragonella-group (K. Sugisima, unpublished data). The Elachista species with these characters almost always pupate beneath a dense silk-sheet, and the pupa is fastened by the spiracular projections inserted in the silksheet (K. Sugisima, unpublished data). Typical Elachista species fasten their pupa by a silk-girdle surrounding the abdomen as well as the cremaster, and if disturbed, they threaten with the dorso-ventral movements of the upper half of the body. The spiracular projections and less-mobile joints may have a strong functional correlation with the pupation habit, and can perhaps occur more or less independently of the phylogenetic relationships. In contrast, the spines on the vertex have no known function and may therefore reflect the phylogenetic relationships more directly. They are absent only in E. solena of E. saccharella-group within the clade. Even if the spiracular processes are somewhat homoplastic, the processes as long as those of E. planicara are known only in the E. saccharella-group. Consequently, the pupal morphology suggests that E. planicara belongs to the E. saccharella-group.

The larva of E. planicara has well-developed spiracular projections on its abdominal segments (Fig. 23; square 11 in Fig. 25). Such projections are known nowhere else within Elachistidae except for E. solena of E. saccharella-group.

Based on the evidence listed above, we conclude that E. planicara is most likely to be an Oriental representative of $E$. saccharella-group, closest to E. solena or E. griseola.

Acknowledgements. The first author thanks Prof. M. Suwa at SEHU for critically reading earlier drafts, and Dr H. Kuroko at Han'nan-si, Ôsaka, Japan for giving supplementary data of the holotype of E. canis, and Mr M. Sano at SEHU for comments on an earlier draft. For offering specimens, we thank the following persons (all in Japan, in alphabetical order): Dr Y. Arita at Zoological Institute, Meijo University; Mr N. Hirano at Hata, Nagano-ken; Mr T. Imai at Yokohama-si, Kanagawa-ken; Mr U. Jinbo at Department of Natural History, Tokyo Metropolitan University; Mr S. Kawahara at Kosimizu-tyô, Hokkaidô; Dr T. Kumata at Ebetu-si, Hokkaidô; Mr I. Ohshima at SEHU; Dr T. Saito at Ikeda-si, Ôsaka-hu; Dr Y. Sakamaki at Agricultural School of Kagoshima University.

\section{References}

Fletcher, T. B. 1933: Life-histories of Indian Microlepidoptera (Second Series). Cosmopterigidae to Neopseustidae. - Imperial Counc. Agric. Res. Sci. Monogr. 4: $1-85+77$ pls.

Kaila, L. 1998: Redescriptions of three Meyrick Asiatic elachistid species, with descriptions of two new species (Lepidoptera, Gelechioidea). — Entomol. Fennica 9: 53-63.

Kaila, L. 1999a: Phylogeny and classification of the Elachistidae s.s. (Lepidoptera: Gelechioidea). — Syst. Ent. 24: 139-169. 
Kaila, L. 1999b: A revision of the Nearctic species of the genus Elachista s.s. III. The bifasciella, prarlineata, saccharella and freyerella groups (Lepidoptera, Elachistidae). - Acta Zool. Fennica 211: 1-235.

Parenti, U. 1983: Elachistidi del Giappone (Lepidoptera, Elachistidae) Bollettino del Museo Regionale di Scienze Naturali - Torino 1: 1-20. [In Italian with English abstract].

Parenti, U. \& Varalda, P. G. 1994: Gli Elachistidi (Lepidoptera, Elachistidae) e le loro pianti ospiti. Bollettino del Museo Regionale di Scienze Naturali - Torino 12: 73-136 [In Italian with English abstract].

Sinev, S. Yu. \& Sruoga, V. A. 1995: New species of the mining moths (Lepidoptera, Elachistidae) from Russian Far East. — Ent. Obozr. 74: 120-137 [In Russian with English abstract].

Sruoga, V. A. 1995: Description of Cosmiotes cornutifera sp. n. and a provisional check-list of Elachistidae fauna of Far-Eastern Russia (Lepidoptera, Elachistidae). - Phegea 23: 157-162.

Sruoga, V. A. 2004: New records and a new synonymy in Elachistidae (Lepidoptera: Gelechioidea) from Far Eastern Russia. - Zootaxa 522: 1-6.

Traugott-Olsen, E. \& Nielsen, E. S. 1977: The Elachistidae (Lepidoptera) of Fennoscandia and Denmark. Fauna Entomol. Scand. 6: 1-299. 